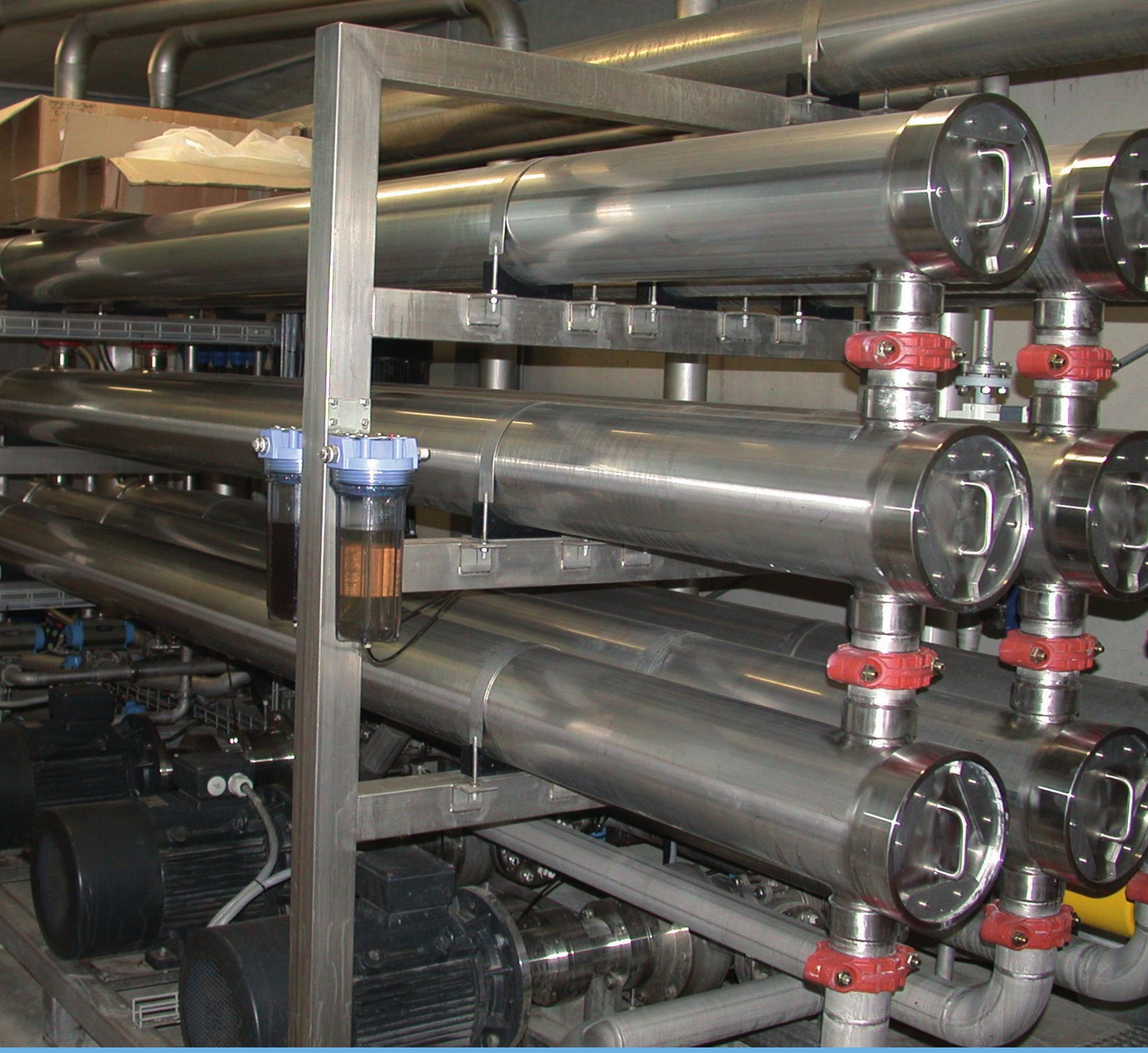

Ammoniak- en broeikasgasemissies bij toepassing van kunstmestvervangers; een quickscan

Gerard Velthof, Phillip Ehlert en Oscar Schoumans

WAGENINGEN
$\square$ UNIVERSITY \& RESEARCH 



\section{Ammoniak- en broeikasgasemissies bij toepassing van kunstmestvervangers; een quickscan}

Gerard Velthof, Phillip Ehlert en Oscar Schoumans

Dit onderzoek is uitgevoerd door Wageningen Environmental Research in opdracht van en gefinancierd door het ministerie van Landbouw, Natuur en Voedselkwaliteit, in het kader van het Beleidsondersteunend onderzoekthema 'A1. Verminderen fossiele nutriënten, water en stikstofdepositie'

(projectnummer BO-43-012.02-042).

Wageningen Environmental Research

Wageningen, november 2021

Gereviewd door:

Inge Regelink, onderzoeker

Akkoord voor publicatie:

Gert Jan Reinds, teamleider van Duurzaam Bodemgebruik

Rapport 3124

ISSN 1566-7197 
Velthof, G.L., P.A.I Ehlert en O.F. Schoumans, 2021. Ammoniak- en broeikasgasemissies bij toepassing van kunstmestvervangers; een quickscan. Wageningen, Wageningen Environmental Research, Rapport 3124. 48 blz.; 5 fig.; 14 tab.; 38 ref.

Trefwoorden: Ammoniak, broeikasgassen, kunstmestvervangers, mestverwerking

Dit rapport is gratis te downloaden van https://doi.org/10.18174/556871 of op www.wur.nl/environmental-research (ga naar 'Wageningen Environmental Research' in de grijze balk onderaan). Wageningen Environmental Research verstrekt geen gedrukte exemplaren van rapporten.

(C) 2021 Wageningen Environmental Research (instituut binnen de rechtspersoon Stichting Wageningen Research), Postbus 47, 6700 AA Wageningen, T 03174807 00, www.wur.nl/environmental-research. Wageningen Environmental Research is onderdeel van Wageningen University \& Research.

- Overname, verveelvoudiging of openbaarmaking van deze uitgave is toegestaan mits met duidelijke bronvermelding.

- Overname, verveelvoudiging of openbaarmaking is niet toegestaan voor commerciële doeleinden en/of geldelijk gewin.

- Overname, verveelvoudiging of openbaarmaking is niet toegestaan voor die gedeelten van deze uitgave waarvan duidelijk is dat de auteursrechten liggen bij derden en/of zijn voorbehouden.

Wageningen Environmental Research aanvaardt geen aansprakelijkheid voor eventuele schade voortvloeiend uit het gebruik van de resultaten van dit onderzoek of de toepassing van de adviezen.

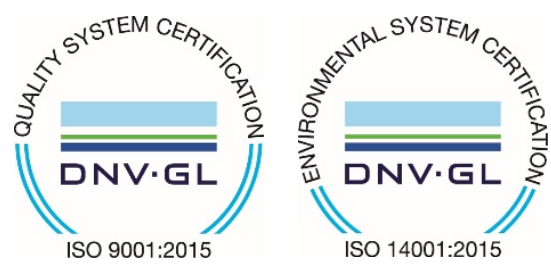

Wageningen Environmental Research werkt sinds 2003 met een ISO 9001 gecertificeerd kwaliteitsmanagementsysteem. In 2006 heeft Wageningen Environmental Research een milieuzorgsysteem geïmplementeerd, gecertificeerd volgens de norm ISO 14001.

Wageningen Environmental Research geeft via ISO 26000 invulling aan haar maatschappelijke verantwoordelijkheid.

Wageningen Environmental Research Rapport 3124 | ISSN 1566-7197

Foto omslag: Gerard Velthof 


\section{Inhoud}

$\begin{array}{ll}\text { Verantwoording } & 5\end{array}$

$\begin{array}{ll}\text { Samenvatting } & 7\end{array}$

1

$\begin{array}{lr}\text { Inleiding } & 9\end{array}$

2

$\begin{array}{ll}\text { Kunstmestvervangers } & 11\end{array}$

$2.1 \quad$ Mestbewerking $\quad 11$

2.2 Mineralenconcentraat $\quad 12$

2.3 Ammoniumsulfaat en ammoniumnitraat $\quad 13$

$\begin{array}{ll}2.4 & \text { Landbouwkundige werking van kunstmestvervangers }\end{array}$

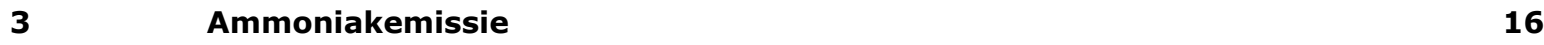

3.1 Ammoniakemissie $\quad 16$

3.2 Ammoniakemissie uit de landbouw 16

3.3 Ammoniakemissie bij toepassing van kunstmestvervangers 16

$\begin{array}{lll}3.3 .1 \quad \text { Inleiding } & 16\end{array}$

$\begin{array}{ll}3.3 .2 & \text { Stal en mestopslag }\end{array}$

$\begin{array}{lll}3.3 .3 & \text { Mestbewerking } & 18\end{array}$

3.3.4 Mestopslag buiten stal 19

3.3.5 Toediening van mest en kunstmest 19

3.3.6 Toediening van kunstmestvervangers: mineralenconcentraten $\quad 21$

3.3.7 Toediening van kunstmestvervangers: ammoniumsulfaat en
ammoniumnitraat

3.3.8 Effect op nationale schaal $\quad 23$

$\begin{array}{lll}3.3 .9 & \text { Conclusie } & 23\end{array}$

4

$\begin{array}{ll}\text { Lachgasemissie } & 24\end{array}$

$\begin{array}{lll}4.1 & \text { Lachgas } & 24\end{array}$

4.2 Lachgasemissie uit de landbouw $\quad 24$

4.3 Lachgasemissie bij toepassing van kunstmestvervangers $\quad 24$

4.3.1 Inleiding $\quad 24$

4.3.2 Stal en mestopslag 25

4.3.3 Mestbewerking 25

4.3.4 Mestopslag buiten stal $\quad 25$

4.3.5 Toediening van mest en kunstmest 25

4.3.6 Toediening van kunstmestvervangers 25

4.3.7 Toediening van de dikke fractie van gescheiden mest 26

4.3.8 Indirecte lachgasemissie 26

4.3.9 Effect op nationale schaal 26

$\begin{array}{ll}4.3 .10 & \text { Conclusie }\end{array}$

$\begin{array}{llr}5 & \text { Methaanemissie } & 27\end{array}$

$\begin{array}{lll}5.1 & \text { Methaanemissie } & 27\end{array}$

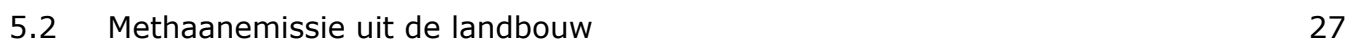

$\begin{array}{lll}\text { 5.2.1 Stal en mestopslag } & 27\end{array}$

5.2.2 Mestbewerking en mestopslag $\quad 27$

$\begin{array}{lll}5.2 .3 & \text { Toediening van meststoffen } & 28\end{array}$

$\begin{array}{lll}5.2 .4 & \text { Conclusie } & 28\end{array}$ 
$6.1 \quad$ Inleiding 29

6.2 Uitgangspunten $\quad 29$

$\begin{array}{lll}6.3 & \text { Resultaten } & 29\end{array}$

6.4 Discussie 30

6.5 Conclusie $\quad 31$

$7 \quad$ Energieverbruik en $\mathrm{CO}_{2}$-emissie $\quad 32$

$\begin{array}{lll}7.1 & \text { Energieverbruik } & 32\end{array}$

$\begin{array}{lll}7.2 & \text { LCA van productie en toepassing mineralenconcentraten } & 35\end{array}$

$\begin{array}{lll}7.3 & \text { Strippen van ammonium uit mest } & 35\end{array}$

$\begin{array}{lll}7.4 & \text { Koolstofopslag in de bodem } & 36\end{array}$

$\begin{array}{lll}7.5 & \text { Conclusie } & 36\end{array}$

$8 \quad$ Samenvatting en conclusies $\quad 38$

$\begin{array}{ll}\text { Literatuur } & 40\end{array}$

$\begin{array}{ll}\text { Bijlage } 1 \text { Berekening met NEMA } & 43\end{array}$ 


\section{Verantwoording}

Rapport: 3124

Projectnummer: BO-43-012.02-042

Wageningen Environmental Research (WENR) hecht grote waarde aan de kwaliteit van zijn eindproducten. Een review van de rapporten op wetenschappelijke kwaliteit door een referent maakt standaard onderdeel uit van ons kwaliteitsbeleid.

Akkoord Referent die het rapport heeft beoordeeld,

functie: Onderzoeker

naam: Inge Regelink

datum: 24-08-2021

Akkoord teamleider voor de inhoud,

naam: Gert Jan Reinds

datum: $\quad 18-10-2021$ 


\section{Samenvatting}

Het ministerie van LNV bereidt een subsidieregeling voor om mestverwerking te stimuleren. Gedacht wordt aan een investeringssubsidie voor de verwerking van mest - in eerste instantie gericht op varkensmest - tot verwerkte mestproducten die stikstofkunstmest kunnen vervangen. Het ministerie van LNV heeft Wageningen Research gevraagd om inzicht te geven in de effecten van het vervangen van stikstofkunstmest door kunstmestvervangers uit dierlijke mest op ammoniak- en broeikasgasemissies. In een quickscan op basis van bestaand onderzoek is nagegaan wat de ammoniak- en broeikasgasemissies zijn bij productie en toepassing van de kunstmestvervangers mineralenconcentraten, ammoniumsulfaat en ammoniumnitraat uit mest. Dit zijn producten die mogelijk op termijn als stikstofkunstmestvervangers in het kader van de Nitraatrichtlijn kunnen worden toegepast. Deze producten worden door de Europese Commissie aangeduid met de term RENURE (REcovered Nitrogen from manURE).

NEMA (National Emission Model Agriculture) is het model dat gebruikt wordt voor de berekening van de emissies van ammoniak en broeikasgassen uit de landbouw op landelijk niveau voor de Nationale Emissie Registratie. Als LNV mestbewerking tot kunstmestvervanger als maatregel wil inzetten in het stikstof- en klimaatdossier, dan moeten de emissies die optreden bij productie en toepassing van kunstmestvervangers opgenomen worden in het NEMA-model. Berekeningen met NEMA voor een scenario waarbij $25 \%$ van de varkensmest in Nederland wordt verwerkt tot mineralenconcentraat laten beperkte effecten zien op emissies: de ammoniakemissie neemt iets toe $\left(0,5 \mathrm{kton} \mathrm{NH}_{3}\right)$, de lachgasemissie neemt iets af $\left(-0,1\right.$ kton $\left.\mathrm{N}_{2} \mathrm{O}\right)$ en de methaanemissie verandert niet. De onzekerheden in deze berekeningen met NEMA zijn echter groot, omdat er weinig gegevens beschikbaar zijn over emissies bij productie en toepassing van kunstmestvervangers waarmee NEMA geparametriseerd kan worden.

Het vervangen van kunstmest door kunstmestvervangers kan leiden tot minder energiegebruik indien het energieverbruik van de productie en toepassing van de kunstmestvervanger lager is dan die van de productie van kunstmest. Het is bekend dat ook mestbewerking veel energie kan vragen, zoals de omgekeerde osmosetechniek bij de productie van mineralenconcentraten en het strippen van ammonium uit mest. Belangrijke factoren hierbij zijn het al dan niet vergisten van de mest, de transportafstand en de landbouwkundige werking van de kunstmestvervanger. Verschillende projecten zullen later in 2021 een beter beeld geven over het energiegebruik bij productie en toepassing van kunstmestvervangers. Afleiden van de voordelen in termen van energieverbruik vraagt om een LCAstudie, waarbij alle processtappen beschouwd worden en vergeleken worden met een referentiescenario.

Als de dikke fractie die wordt geproduceerd tijdens productie van kunstmestvervangers aan Nederlandse landbouwgronden wordt toegediend, kan de toegevoegde koolstof bijdragen aan de vermindering van $\mathrm{CO}_{2}$-emissies door koolstofopslag. Echter, de dosering van organische stof wordt hierbij beperkt door het hoge fosfaatgehalte van dikke fracties uit mest. Er wordt geëxperimenteerd met technieken om fosfaat uit mest te halen, zodat er een fosfaatarme dikke fractie overblijft, waarmee binnen de fosfaatgebruiksnormen meer organische stof aan landbouwgronden kan worden toegediend.

Deze quickscan geeft een eerste indruk van de effecten van toepassing van kunstmestvervangers geproduceerd uit mest op ammoniak- en broeikasgasemissies. Als er aanvullende maatregelen worden genomen (zoals een korte opslagduur en emissiearme opslag van de mest en mestproducten en verbeterde emissiearme toediening van producten uit mestbewerking), dan zijn er perspectieven om ammoniak- en broeikasgasemissies te beperken door vervanging van kunstmest door kunstmestvervangers. Er zijn echter veel onzekerheden en de rekenmethoden van emissies die voor het Nederlandse beleid worden toegepast, zoals NEMA, moeten worden verbeterd. Hiervoor is experimenteel onderzoek nodig. Ook is meer onderzoek nodig naar het energieverbruik tijdens mestbewerking. 
In 2021 en daarna zijn er nog diverse lopende projecten naar de ammoniak- en broeikasgasemissies en het energieverbruik bij productie en toepassing van kunstmestvervangers alsmede de landbouwkundige werking van deze meststoffen. Er is echter geen overzicht of dit onderzoek alle vragen beantwoordt en bruikbare gegevens oplevert voor inpassing van kunstmestvervangers in het NEMA-model. Geadviseerd wordt om in beeld te brengen welk onderzoek er loopt en of er extra onderzoek nodig is op onderdelen die nu niet worden onderzocht teneinde het NEMA-model te kunnen parametriseren. 


\section{$1 \quad$ Inleiding}

Er zijn ambitieuze doelstellingen om de emissies van ammoniak en broeikasgassen uit de Nederlandse landbouw te reduceren. Reductie van ammoniakemissie moet leiden tot minder stikstofdepositie op natuurgebieden, zodat Nederland kan voldoen aan de eisen gesteld uit de Vogel- en Habitatrichtlijn. ${ }^{1}$ Maatregelen om ammoniakemissie te reduceren, zijn onder andere verlaging van het eiwitgehalte in het voer, emissiearme stallen, meer beweiding en emissiearme mesttoediening. Mestverwerking tot meststoffen die kunstmest kunnen vervangen, kan mogelijk ook een bijdrage leveren aan het reduceren van ammoniakemissie.

In het kader van het Klimaatakkoord is een groot aantal afspraken gemaakt om maatregelen te nemen om de emissie van broeikasgassen te reduceren. ${ }^{2}$ De productie van kunstmest kost veel energie. Het vervangen van kunstmest door meststoffen uit dierlijke mest kan binnen Nederland mogelijk leiden tot minder broeikasgasemissies. Niet alleen de $\mathrm{CO}_{2}$-emissie bij productie van meststoffen moet hierbij worden beschouwd, maar ook de emissies van methaan $\left(\mathrm{CH}_{4}\right)$ en lachgas $\left(\mathrm{N}_{2} \mathrm{O}\right)$ uit de opslag en toepassing van de mest en meststoffen.

Kunstmestvervangers uit dierlijke mest vallen vooralsnog onder de noemer 'dierlijke mest', waardoor de dosering hiervan beperkt wordt door de maatregelen zoals beschreven in de Nitraatrichtlijn. De Nitraatrichtlijn heeft als doel de nitraatuitspoeling uit de landbouw naar grond- en oppervlaktewater en de eutrofiëring van oppervlaktewater te verminderen. Een van de maatregelen uit deze richtlijn is dat er maximaal $170 \mathrm{~kg}$ stikstof $(\mathrm{N})$ per ha per jaar via dierlijke mest mag worden toegediend aan landbouwgrond. Lidstaten mogen van deze maatregel afwijken via een derogatie, mits er geen afbreuk wordt gedaan aan het bereiken van de doelstellingen. Nederland heeft sinds 2006 een derogatie voor het gebruik van graasdierenmest voor bedrijven met meer dan 70\% - en sinds 2014 meer dan 80\% grasland. Sinds 2014 geldt een derogatie van $230 \mathrm{~kg} \mathrm{~N}$ per ha voor de zuidelijke zand- en lössregio en van $250 \mathrm{~kg} \mathrm{~N}$ per ha voor het overige deel van Nederland (overige zandregio's en de klei- en veenregio's).

De mogelijkheden om kunstmestvervangers uit dierlijke mest toe te passen als kunstmest, boven de gebruiksnorm voor stikstof uit dierlijke mest, worden waarschijnlijk groter. Joint Research Center (JRC), het onderzoeksinstituut van de Europese Commissie, heeft in het kader van het project SAFEMANURE criteria opgesteld om te bepalen wanneer producten afkomstig uit dierlijke mest gebruikt kunnen worden als kunstmest in het kader van de Nitraatrichtlijn (Huygens et al., 2020). Deze meststoffen vallen dan niet binnen de gebruiksnorm voor stikstof uit dierlijke mest van $170 \mathrm{~kg} \mathrm{~N}$ per ha (of hoger, indien er een derogatie geldt). De stikstof- en fosfaatgebruiksnormen uit het mestbeleid blijven wel gelden voor deze meststoffen. $\mathrm{Er}$ is een nieuwe meststofcategorie geïntroduceerd: RENURE (REcovered Nitrogen from manURE). RENURE wordt door JRC als volgt gedefinieerd: "any nitrogen containing substance fully or partially derived from livestock manure through processing under controlled conditions that can be used in areas with water pollution by nitrogen following the same provisions applied to nitrogen containing chemical fertilisers as defined in the Nitrates Directive (91/676/EEC), while providing adequate agronomic benefits to enhance plant growth."

Mineralenconcentraten, geproduceerd door middel van scheiding en omgekeerde osmose, en ammoniumsulfaat en ammoniumnitraat, geproduceerd door middel van het strippen en absorberen van ammonium uit mest, zijn meststoffen die aan de door JRC opgestelde criteria voor RENUREproducten kunnen voldoen (VCM, 2020). De definitieve beslissing over toelating van RENUREproducten moet nog in EU-verband worden genomen.

\footnotetext{
https://www.aanpakstikstof.nl/.

2 https://www.klimaatakkoord.nl/klimaatakkoord.
} 
Het ministerie van LNV bereidt een subsidieregeling voor om mestverwerking te stimuleren. Gedacht wordt aan een investeringssubsidie voor de verwerking van mest - in eerste instantie gericht op varkensmest - tot verwerkte mestproducten die stikstofkunstmest kunnen vervangen. Het ministerie van LNV heeft Wageningen Environmental Research gevraagd om inzicht te geven in de effecten van het vervangen van stikstofkunstmest door producten uit verwerkte mest op de emissies van ammoniak en broeikasgassen.

In een quickscan op basis van bestaand onderzoek is nagegaan wat de emissies van ammoniak en broeikasgassen zijn bij productie en toepassing van mineralenconcentraten, ammoniumsulfaat en ammoniumnitraat uit mest. Opgemerkt wordt dat er verschillende lopende projecten zijn waarin onderzoek wordt uitgevoerd naar emissies uit deze producten (zie hoofdstuk 8), zodat de inzichten in de effecten van kunstmestvervangers op emissies van ammoniak en broeikasgassen in de komende jaren mogelijk nog verbeteren.

De onderzoekers bedanken Cor van Bruggen (CBS) voor de berekening van de effecten van mestbewerking tot mineralenconcentraten (Hoofdstuk 6 en Bijlage 1) en Nico Verdoes van Wageningen Livestock Research voor het leveren van input voor hoofdstuk 7 over energieverbruik en $\mathrm{CO}_{2}$-emissie. 


\section{$2 \quad$ Kunstmestvervangers}

\section{$2.1 \quad$ Mestbewerking}

$\mathrm{Er}$ is een groot aantal technieken om mest te be- en verwerken, waarbij allerlei producten ontstaan die als stikstof-, fosfaat- en/of kaliummeststof kunnen worden toegediend (Figuur 1).

De begrippen mestverwerking en mestbewerking worden vaak door elkaar gebruikt. In de Meststoffenwet is de volgende definitie opgenomen van 'mestverwerking':

- het behandelen van dierlijke meststoffen tot een eindproduct dat bestaat uit:

- as, waarin maximaal $10 \%$ organische stof aanwezig is als mestkorrels;

- mengsel van gedroogd digestaat en verwerkt categorie 1-materiaal, als bedoeld in artikel 8 van de Verordening dierlijke bijproducten;

- het exporteren van dierlijke meststoffen.

Mestkorrels zijn een product van mestverwerking volgens de Meststoffenwet. Bij mestverwerking worden de nutriënten buiten de Nederlandse landbouw geplaatst.

Bij 'mestbewerking' gaat het om het verwaarden van mest door toepassing van scheidingstechnieken. Mestbewerkingstechnieken zijn onder andere het scheiden, centrifugeren, strippen, vergisten, beluchten, composteren en hygiëniseren van mest. De productie van mineralenconcentraten waarbij mest wordt gescheiden en omgekeerde osmose wordt toegepast, is een vorm van mestbewerking. Bij mestbewerking blijven de nutriënten (deels) in de landbouw. Mestbewerking en mestverwerking kunnen ook samen worden toegepast, bijvoorbeeld als de dunne fractie van gescheiden mest in de Nederlandse landbouw wordt toegepast en de dikke fractie van gescheiden mest wordt geëxporteerd.

In dit rapport wordt ingegaan op de drie type producten uit mestbewerking, die mogelijk op termijn als stikstofkunstmestvervangers (RENURE) kunnen worden toegepast: mineralenconcentraat, ammoniumsulfaat en ammoniumnitraat. 


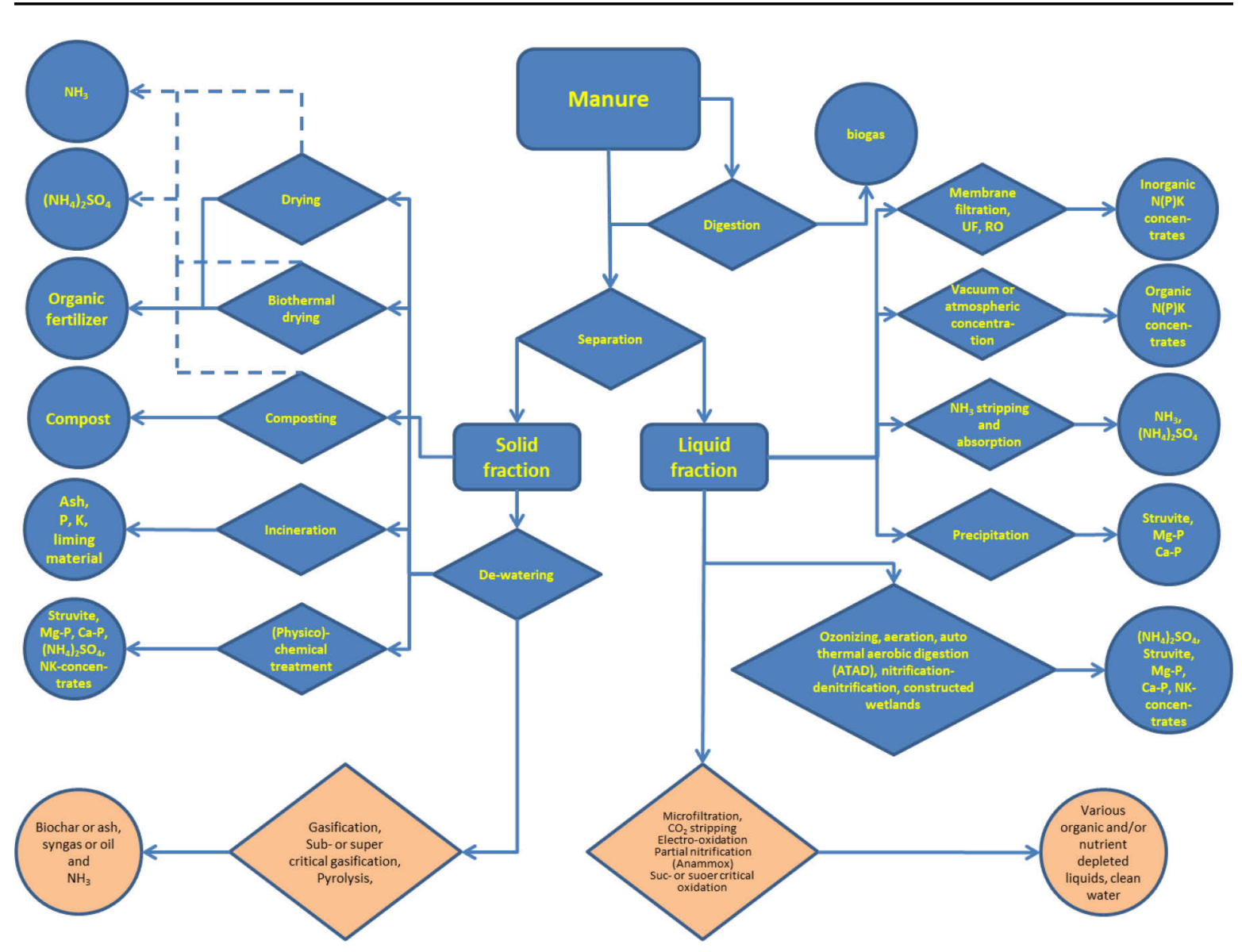

Figuur 1 Mestverwerkingstechnieken.

\section{$2.2 \quad$ Mineralenconcentraat}

In Figuur 2 staat een schema weergegeven van de productie van mineralenconcentraten. Andere varianten zijn mogelijk, maar in het algemeen komt het erop neer dat drijfmest, al dan niet na (co)vergisting, wordt gescheiden met een hightech scheidingsmethode (om vaste delen uit de mest af te scheiden van de vloeibare fractie), waarna het vloeibare effluent wordt geconcentreerd via omgekeerde osmose (Hoeksma et al., 2020). Er ontstaan twee meststoffen (Tabel 1):

- het mineralenconcentraat, een vloeibare fractie, rijk aan kalium en stikstof, waarbij de concentratie TotaalAmmoniakaal $\mathrm{N}$ (TAN) hoog is en het aandeel organische $\mathrm{N}$ laag is. Het gehalte aan fosfaat is laag. De pH is relatief hoog (vaak hoger dan 7,5) en;

- de dikke fractie, een fractie rijk aan organische stof, fosfaat en organische stikstof. De dikke fractie bevat minder TAN dan de vloeibare fractie en drijfmest, maar het aandeel is niet te verwaarlozen.

Daarnaast ontstaat er een permeaat, een vloeistof met lage concentraties van elementen, dat, vaak na een zuivering, kan worden geloosd op het land of oppervlaktewater. 
Tabel 1 Gemiddelde samenstelling van onbehandelde varkensdrijfmest, dikke fractie en mineralenconcentraat van varkensmest (Hoeksma et al., 202111).

\begin{tabular}{|c|c|c|c|c|}
\hline Parameter & Unit & Onbehandelde mest & Dikke fractie & Mineralenconcentraat \\
\hline Droge stof & $\mathrm{g} / \mathrm{kg}$ & 61 & 283 & 35 \\
\hline Organische stof & $\mathrm{g} / \mathrm{kg}$ droge stof & 654 & 753 & 296 \\
\hline Totaal C & $\mathrm{mg} / \mathrm{kg}$ & 2343 & 2776 & 3357 \\
\hline Totaal N & $\mathrm{mg} / \mathrm{kg}$ & 4687 & 11972 & 6356 \\
\hline TAN/Totaal N & - & 0,59 & 0,22 & 0,86 \\
\hline $\mathrm{P}$ & $\mathrm{mg} / \mathrm{kg}$ & 1311 & 7140 & 72 \\
\hline $\mathrm{P}-\mathrm{PO}_{4}$ & $\mathrm{mg} / \mathrm{kg}$ & 198 & 351 & 40 \\
\hline $\mathrm{K}$ & $\mathrm{mg} / \mathrm{kg}$ & 3489 & 3846 & 7183 \\
\hline $\mathrm{Ca}$ & $\mathrm{mg} / \mathrm{kg}$ & 1837 & 9113 & 214 \\
\hline $\mathrm{Mg}$ & $\mathrm{mg} / \mathrm{kg}$ & 921 & 4546 & 251 \\
\hline $\mathrm{Na}$ & $\mathrm{mg} / \mathrm{kg}$ & 982 & 914 & 2169 \\
\hline S & $\mathrm{mg} / \mathrm{kg}$ & 748 & 4089 & 3623 \\
\hline $\mathrm{Cl}-$ & $\mathrm{mg} / \mathrm{kg}$ & 1570 & 1023 & 3527 \\
\hline
\end{tabular}

$\left.{ }^{1}\right)$ Resultaten van een monitoring in 2019 en 2020 van negen installaties.

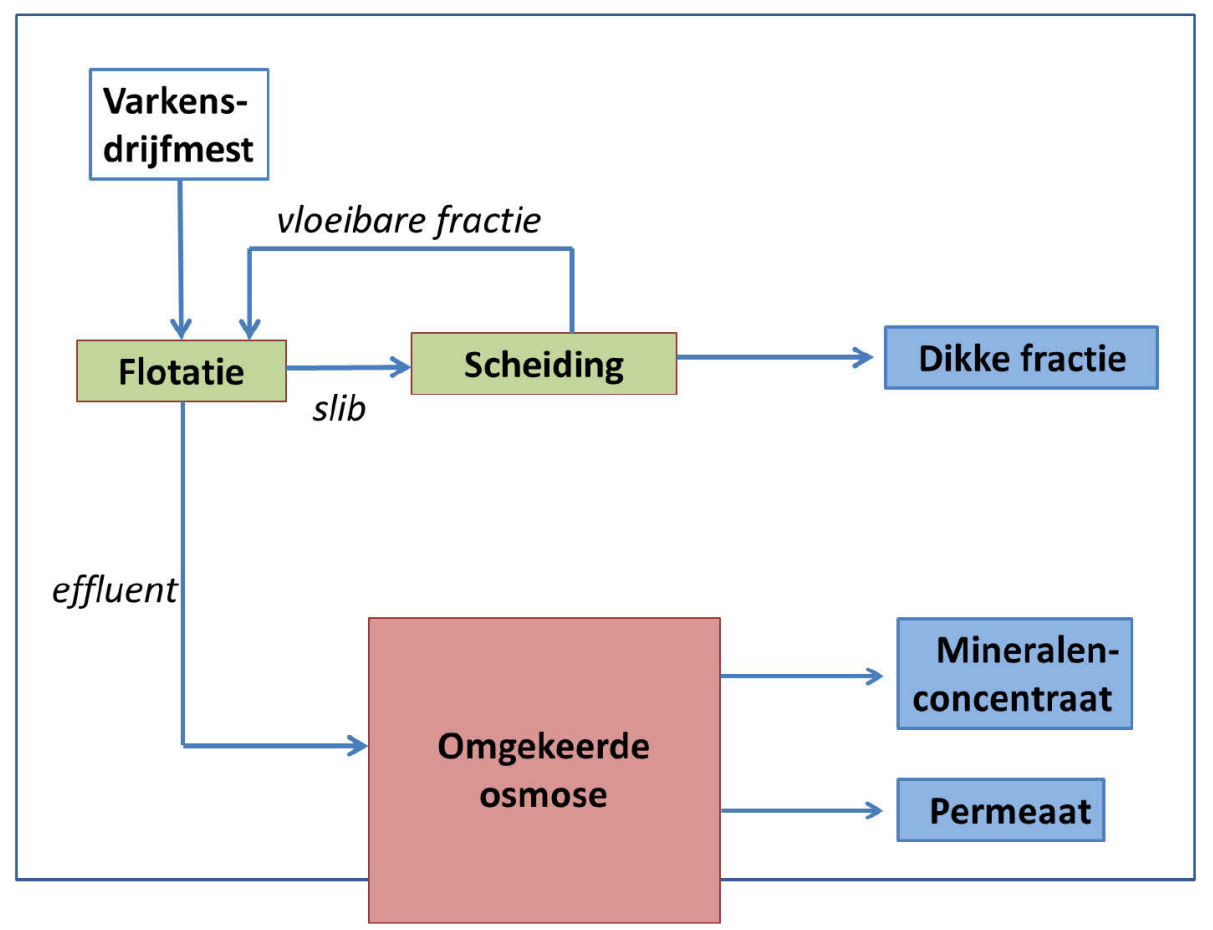

Figuur 2 Schema met een voorbeeld van de productie van mineralenconcentraat.

\subsection{Ammoniumsulfaat en ammoniumnitraat}

Er bestaan verschillende technieken om ammoniak uit mest te strippen en de ammonium als meststof (ammoniumsulfaat of ammoniumnitraat) te gebruiken; zie Figuur 3. Bij ammoniumsulfaat wordt zwavelzuur gebruikt en bij ammoniumnitraat wordt salpeterzuur gebruikt om ammoniak dat uit mest wordt gestript op te vangen. Er wordt in deze quickscan verder niet ingegaan op de verschillende technieken om ammoniak uit mest te strippen. 
Het ammoniumsulfaat en het ammoniumnitraat die door het strippen van mest ontstaan, zijn vloeibare meststoffen. De samenstelling (concentraties, zoutsterkte $(E C)$ en $\mathrm{pH}$ ) is afhankelijk van het proces. De $\mathrm{pH}$ varieert van zuur tot neutraal en is eventueel te sturen door de tijdsduur waarin ammoniak wordt gestript. Het ammoniumsulfaat en het ammoniumnitraat bestaan voor 100 procent uit minerale stikstof. Bij ammoniumsulfaat bestaat de stikstof alleen uit ammonium en bij ammoniumnitraat is minimaal de helft van de stikstof aanwezig als nitraat vanwege het gebruik van salpeterzuur voor het binden van de ammonium.

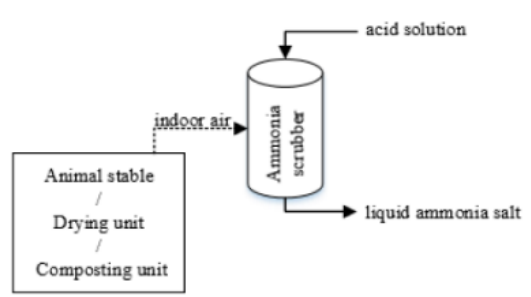

PW1: Air cleaning pathway

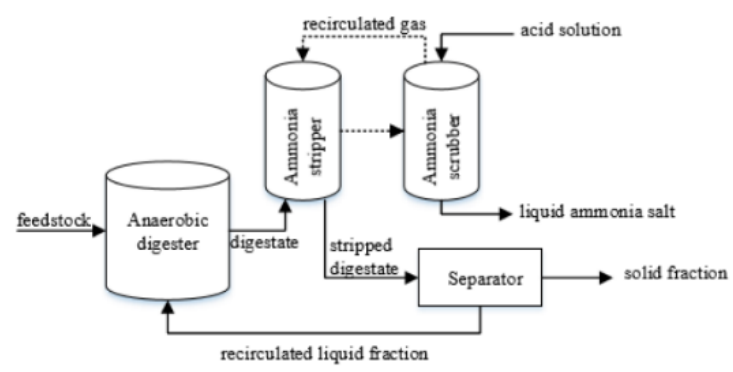

PW2: Ammonia removal and recirculation pathway (Example 2 with liquid fraction of digestate recirculation)

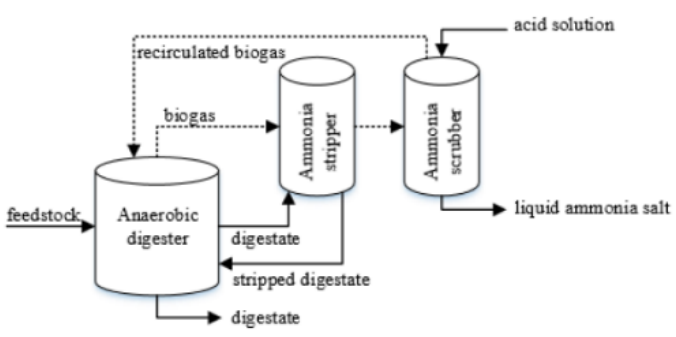

PW2: Ammonia removal and recirculation pathway (Example 1 with digestate recirculation)

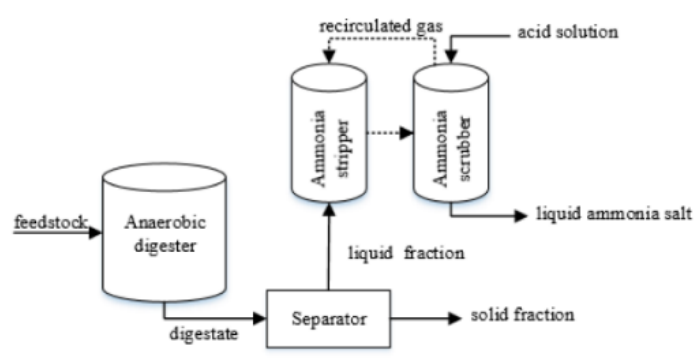

PW3: End-of-pipe pathway

Figuur 3 Schema's van strippen van ammonium uit mest (Ehlert et al., 2019).

\subsection{Landbouwkundige werking van kunstmestvervangers}

De wettelijke werkingscoëfficiënt van mineralenconcentraat zal waarschijnlijk $100 \%$ zijn als mineralenconcentraat als kunstmestvervanger (RENURE) is toegestaan.

In potproeven was de stikstofwerking van mineralenconcentraten gemiddeld zo'n $90 \%$ ten opzichte van KAS, maar in veldproeven was de werking lager (72-84\% voor bouwland en $54-81 \%$ voor grasland; Velthof et al., 2020). Dit betekent dat er meer mineralenconcentraten moeten worden toegediend dan kunstmest om eenzelfde hoeveelheid werkzame stikstof toe te dienen als kunstmest.

In recente veldproeven, uitgevoerd in het kader van het pilotproject Kunstmestvrije Achterhoek, werden werkingscoëfficiënten van $90 \%$ of meer vastgesteld voor een blend van mineralenconcentraat, ammoniumsulfaat en synthetische kunstmest (ureum) (Ehlert en Van der Lippe, 2020; Ehlert, 2020).

De stikstofwerking van de vaste fractie van gescheiden mest is laag; 32 tot $55 \%$ in een proef met aardappelen en $64 \%$ in een proef met snijmaïs (Velthof, 2015). De wettelijke werkingscoëfficiënt van vaste varkensmest is $55 \%$ en deze is lager dan onbehandelde varkensmest $(60-80 \%)$. In de praktijk beperkt de fosfaatgebruiksnorm en niet de werkzame stikstofgebruiksnorm de hoeveel vaste fractie die kan worden toegediend.

Scenarioberekeningen laten zien dat grootschalige toepassing van mineralenconcentraten onder de toen veronderstelde condities voor 2015 (gebruiksnormen 2015, excreties 2009 en derogatie) leidt tot een hogere mestplaatsingsruimte voor nutriënten uit mest, waardoor er minder mestexport nodig is (Lesschen et al., 2011). Hierdoor neemt het gebruik van zowel (conventionele) stikstof- als 
fosfaatkunstmest in Nederland af. Uit deze studie bleek verder dat door grootschalige productie en toepassing van mineralenconcentraten geen ruimte ontstaat binnen de gebruiksnormen voor een hogere mestproductie en daardoor grotere omvang van de veestapel.

De stikstofwerking van ammoniumsulfaat en ammoniumnitraat is gemiddeld genomen vergelijkbaar met die van kunstmest kalkammonsalpeter (KAS; Ehlert et al., 2019).

Conclusie: de stikstofwerking van mineralenconcentraten is lager dan die van kunstmest en die van de dikke fractie is lager dan die van drijfmest. De werkelijke en wettelijke stikstofwerking van meststoffen kan het gebruik van meststoffen binnen de gebruiksnormen van stikstof, fosfaat en dierlijk mest (en de mestmarkt) veranderen en daarmee een effect hebben op de emissies van ammoniak en lachgas bij toedienen van deze meststoffen. Uit een scenarioberekening blijkt dat bij grootschalige productie en toepassing van mineralenconcentraten er geen ruimte binnen de gebruiksnormen ontstaat voor een hogere mestproductie (en grotere omvang veestapel). De stikstofwerking van ammoniumsulfaat en ammoniumnitraat is gemiddeld genomen vergelijkbaar met die van de kunstmest KAS. 


\section{Ammoniakemissie}

\subsection{Ammoniakemissie}

Ammoniak $\left(\mathrm{NH}_{3}\right)$ wordt onder basische omstandigheden uit ammonium $\left(\mathrm{NH}_{4}{ }^{+}\right)$gevormd. Ammoniakemissie naar de lucht is een fysisch-chemisch proces, waarvan de snelheid en hoeveelheid vooral door fysische (luchtsnelheid, oppervlak, temperatuur etc.) en chemische factoren $\left(\mathrm{NH}_{4}{ }^{+}-\right.$ concentratie, $\mathrm{pH}$, ionsterkte etc.) worden bepaald. Mest bevat veel ammonium (ammoniakale stikstof) en is meestal basisch $(\mathrm{pH}>7,0)$ waardoor het risico op ammoniakemissie uit mest hoog is.

\subsection{Ammoniakemissie uit de landbouw}

In Tabel 2 staat de ammoniakemissie uit de landbouw weergegeven, zoals berekend met National Emission Model Agriculture (NEMA). Dit zijn de emissiecijfers die EmissieRegistratie hanteert en die Nederland internationaal rapporteert aan de Europese Commissie (NEC-richtlijn) en Verenigde Naties (UNECE Gothenburg Protocol). Deze emissiecijfers worden ook gebruikt in het stikstofbeleid en zijn input voor de depositieberekeningen met het model AERIUS.

De totale ammoniakemissie uit de landbouw in Nederland was in 2019 105,6 miljoen kg (kton) $\mathrm{NH}_{3}$ (= 87 kton $\mathrm{NH}_{3}-\mathrm{N}$ ); zie Tabel 2. De focus van deze quickscan ligt op varkensmest. De emissie uit varkensmest was 18,4 kton $\mathrm{NH}_{3}$, waarvan 13,1 kton uit de stal en opslag, 4,3 kton uit mesttoediening en 1,1 kton uit mestbewerking. De emissie uit kunstmest, inclusief spuiwater uit luchtwassers, was 8,8 kton $\mathrm{NH}_{3}$.

\subsection{Ammoniakemissie bij toepassing van kunstmestvervangers}

\subsubsection{Inleiding}

De vraag die in deze quickscan moet worden beantwoord, is of de ammoniakemissie uit een landbouwsysteem gebaseerd op productie en toepassing van mineralenconcentraat, ammonium sulfaat of ammoniumnitraat als kunstmestvervanger anders is dan die van de huidige praktijk op basis van onbehandelde drijfmest met kunstmest.

De volgende emissiebronnen van ammoniak kunnen worden onderscheiden:

- Stal en mestopslag in de stal;

- Mestbewerking;

- Opslag van onbehandelde mest buiten de stal;

- Opslag van mineralenconcentraat buiten de stal;

- Toediening van meststoffen (onbehandelde mest, mineralenconcentraat, vaste fractie en kunstmest). Hierbij wordt opgemerkt dat er ook sprake kan zijn van mengsels (blends) van meststoffen, zoals het mengen van mineralenconcentraat met ammonium sulfaat en/of ammoniumnitraat. Dit gebeurt bijvoorbeeld bij de groene weide meststof van Groot Zevert Vergisting. 


\subsubsection{Stal en mestopslag}

De stal en de mestopslag in de stal zijn een grote bron van ammoniakemissie (Tabel 2). De grootte van de emissie is sterk afhankelijk van het staltype en of er emissiebeperkende maatregelen worden genomen. In het kader van de Regeling Ammoniak en Veehouderij (RAV) is een groot aantal stalsystemen met emissiebeperkende maatregelen (en emissiefactoren) opgenomen, zoals luchtwassers en vloeraanpassingen. ${ }^{3}$ Als productie van mineralenconcentraten of het strippen van ammonium uit mest leidt tot een kortere opslagduur van drijfmest in de stal (bijvoorbeeld door een snellere afvoer van de drijfmest naar de mestverwerker), dan zal de ammoniakemissie uit de stal en mestopslag lager zijn. Hierbij moet wel worden opgemerkt dat de berekening van emissies in NEMA op basis van de hoeveelheid stikstof in de mestopslag wordt berekend (dus als de hoeveelheid mest in de opslag halveert, dan halveert de berekende emissie). In werkelijkheid is het emitterende oppervlak een belangrijke factor die emissie bepaalt en die verandert niet als er minder mest in de opslag zit (dus halvering van hoeveelheid mest in de opslag, zal in werkelijkheid waarschijnlijk tot een lagere reductie in ammoniakemissie leiden dan 50\%). Het toevoegen van de opslagduur van de drijfmest als parameter in NEMA voor de berekening van de ammoniakemissie vraagt om nader onderzoek om de emissiefactor als functie van de opslagduur vast te stellen.

Tabel 2 Ammoniakemissie uit dierlijke mest, kunstmest en overige bronnen binnen de landbouw (m/n. $\mathrm{kg} \mathrm{NH} 3$ per jaar) in 2019. Resultaten van berekeningen met NEMA (Van Bruggen et al., 2021).

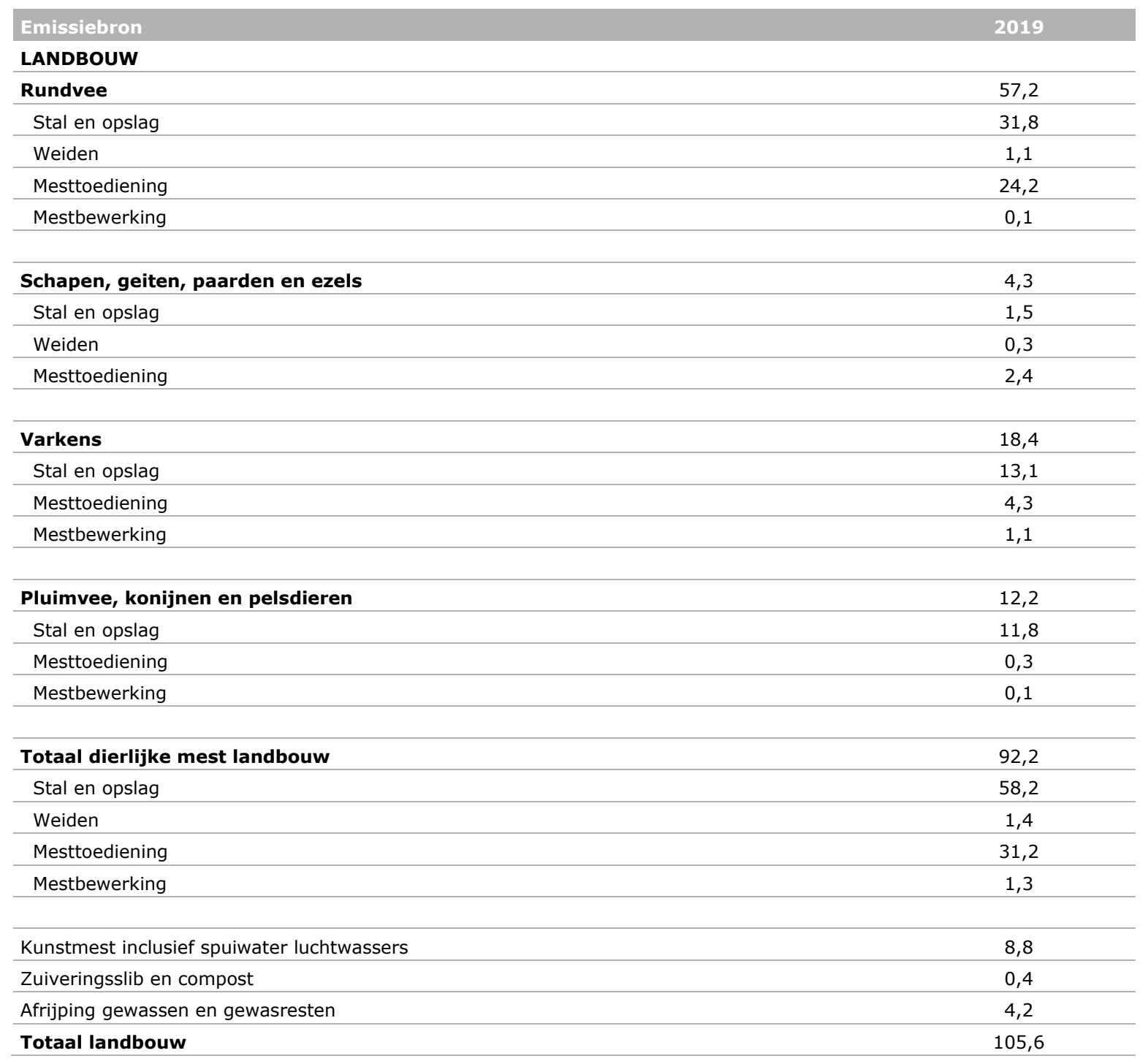

3 https://www.infomil.nl/onderwerpen/landbouw/ammoniak/rav-0/. 


\subsubsection{Mestbewerking}

Tijdens het scheidingsproces wordt mest blootgesteld aan lucht (bijvoorbeeld bij mesttransport op een band of beluchting in een flotatietank) en zal er ammoniakemissie optreden. Bij productie van mineralenconcentraten is dit een extra bron van ammoniak, omdat de mest eerst wordt gescheiden. In NEMA wordt de emissie tijdens bewerking meegerekend, waarbij zowel de emissie van het mestbewerkingsproces zelf als die van de opslag van de producten uit mestbewerking wordt berekend (Tabel 3). De onzekerheden in de emissiefactoren zijn groot en effecten van emissiebeperkende maatregelen, zoals de aanwezigheid van afzuigsystemen gekoppeld aan luchtwassers, zijn niet meegenomen. In NEMA wordt ervan uitgegaan dat de ammoniakemissie uit stallen en mestopslag niet verandert indien er mestbewerking plaatsvindt. In 2019 was de berekende ammoniakemissie uit bewerking van varkensmest 1,1 kton $\mathrm{NH}_{3}$ (Tabel 2).

Tabel 3 Emissiefactoren in NEMA voor mestbewerking in $\mathrm{kg} \mathrm{N}$ per $\mathrm{kg} \mathrm{N}$ in aangevoerde mest, inclusief productie van mineralenconcentraten (Van Bruggen et al., 2020; Melse en Groenestein, 2016).

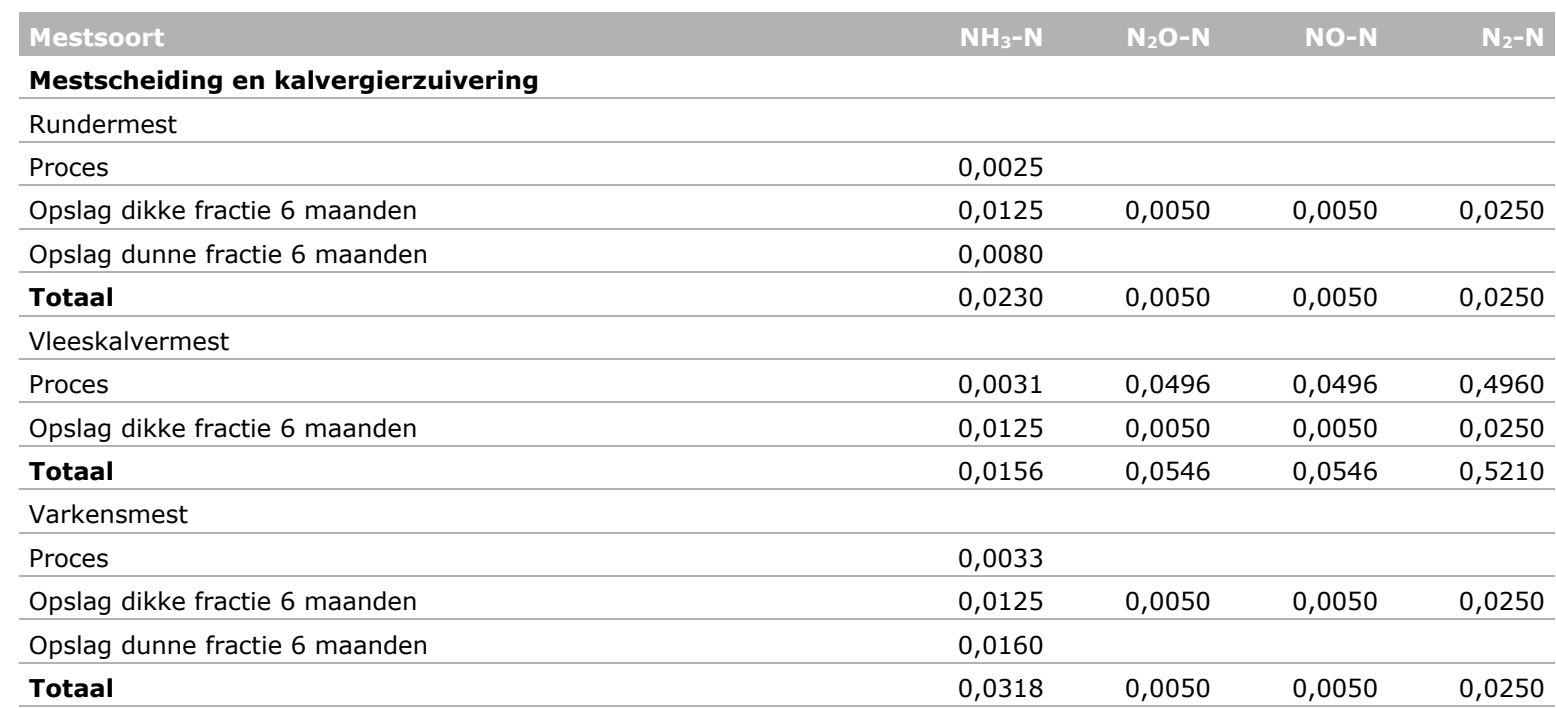

Productie van mineralenconcentraat

\begin{tabular}{|c|c|c|c|c|}
\hline \multicolumn{5}{|l|}{ Varkensmest } \\
\hline Proces & 0,0033 & & & \\
\hline Opslag dikke fractie 6 maanden & 0,0125 & 0,0050 & 0,0050 & 0,0250 \\
\hline Totaal & 0,0318 & 0,0050 & 0,0050 & 0,0250 \\
\hline
\end{tabular}

Mestvergisting / Manure digestion

Rundermest - opslag digestaat

Varkensmest - opslag digestaat

0,0200

Mest drogen en korrelen

Pluimveemest

Proces $\quad 0,0135$

$\begin{array}{lr}\text { Korte vooropslag } & 0,0008\end{array}$

$\begin{array}{lr}\text { Totaal } & 0,0143\end{array}$ 


\subsubsection{Mestopslag buiten stal}

Opslag van drijfmest buiten de stal is een beperkte bron van ammoniakemissie, omdat de mest verplicht afgedekt wordt opgeslagen (emissiefactor ongeveer $2 \%$ van de opgeslagen varkensdrijfmest). In 2019 werd $19 \%$ van de geproduceerde varkensmest buiten opgeslagen (Van Bruggen et al., 2021). Als mineralenconcentraten worden geproduceerd of ammonium wordt uit de mest gestript voordat onbehandelde mest buiten wordt opgeslagen, valt deze bron (opslag buiten) van emissie weg. Mocht de mest wel eerst buiten worden opgeslagen, dan is er geen verschil tussen een systeem met en zonder mineralenconcentraten/strippen.

Door het hoge TAN-gehalte in combinatie met een hoge $\mathrm{pH}$ is er een duidelijk risico op ammoniakemissie uit mineralenconcentraten tijdens opslag. Het opslaan van mineralenconcentraten in een dichte opslag/silo, zoals verplicht, zal de ammoniakemissie sterk beperken. Er zal geen ammoniakemissie optreden bij de opslag van ammoniumsulfaat en ammoniumnitraat, omdat de zuurgraad van deze meststoffen laag tot neutraal is.

In de dikke fractie zit nog steeds veel TAN, die gevoelig is voor ammoniakemissie (Velthof et al., 2020). Opslag van de dikke fractie leidt tot een extra bron in het productiesysteem van mineralenconcentraten. In de Nederlandse rekenmethodiek voor ammoniakemissie (NEMA) wordt uitgegaan van een ammoniakemissie van 3,2\% van de ingaande $\mathrm{N}$ gedurende het productieproces van mineralenconcentraten en de opslag van de dikke en dunne fractie (Tabel 3).

\subsubsection{Toediening van mest en kunstmest}

De emissie van aan de bodem toegediende onbehandelde mest varieert van $2 \%$ (bouwlandinjectie) tot $17 \%$ (zodenbemesting op grasland) van de TAN, en hoger bij technieken die in Nederland niet meer zijn toegestaan, zoals bovengrondse toediening en sleepvoet met onverdunde drijfmest (Tabel 4). Met ingang van 2019 moet op grasland bij sleepvoet of sleufkouter de mest worden verdund bij gehele of gedeeltelijke toediening op de grond. Bij toediening van verdunde mest met sleepvoet aan grasland geldt dezelfde emissiefactor als voor zodenbemesting aan grasland.

De gemiddelde ammoniakemissie uit kunstmest varieert van 0 (nitraatkunstmest) tot 14,3\% voor ureum (Tabel 5). De emissiefactor voor KAS, de meest toegepaste kunstmeststof in Nederland (Figuur 4), is 2,5\%. De emissiefactoren zijn afgeleid op basis van een internationale studie van Bouwman et al. (2002) en de onzekerheid in de emissiefactoren van stikstofkunstmestsoorten onder Nederlandse omstandigheden is groot. In onderzoek dat in 2021 en daarna is gepland in het Nationaal Kennisprogramma Stikstof, worden de emissiefactoren van verschillende kunstmeststoffen opnieuw vastgesteld.

Tabel 4 Emissiefactor voor $\mathrm{NH}_{3}-\mathrm{N}$ voor dierlijke mest in de landbouw (\% van toegediende TAN; Van Bruggen et al., 2021).

\begin{tabular}{lr} 
Toepassingsmethode & Emissiefactor, \% van TAN \\
\hline Grasland & 17,0 \\
\hline Zodenbemester & 17,0 \\
\hline Sleufkouter (verdunde mest) & 17,0 \\
\hline Sleepvoet (verdunde mest) & 68,0 \\
\hline Bovengronds & 2,0 \\
\hline Bouwland & 24,0 \\
\hline Mestinjectie & 22,0 \\
\hline Zodenbemester & 46,0 \\
\hline Inwerken in één werkgang & 69,0 \\
\hline Inwerken in twee werkgangen & \\
\hline Bovengronds &
\end{tabular}


Tabel 5 Emissiefactor voor $\mathrm{NH}_{3}-\mathrm{N}$ voor kunstmest (\% van toegediende $\mathrm{N}$ ) (Van Bruggen et al., 2021)

\begin{tabular}{|c|c|}
\hline Kunstmestsoort & EF $\left.\mathrm{NH}_{3}-\mathrm{N}^{1}\right)(\%)$ \\
\hline Ammoniumnitraat & 5,2 \\
\hline Ammoniumsulfaat & 11,3 \\
\hline Chilisalpeter & 0 \\
\hline Diammoniumfofaat & 7,4 \\
\hline Kalisalpeter & 0 \\
\hline Kalkammonsalpeter & 2,5 \\
\hline Kalksalpeter & 0 \\
\hline Monoammoniumfosfaat & 7,4 \\
\hline Stikstofmagnesia & 2,5 \\
\hline \multicolumn{2}{|l|}{ Ureum: } \\
\hline korrelvormig incl. ureum met nitrificatieremmer & 14,3 \\
\hline korrelvormig met ureaseremmer & 5,9 \\
\hline vloeibaar, oppervlakkig toegediend & 7,5 \\
\hline vloeibaar, geïnjecteerd & 1,5 \\
\hline vloeibaar, met ureaseremmer & 3,1 \\
\hline ureum in glastuinbouw & 0 \\
\hline Vloeibare ammoniak & 2,3 \\
\hline
\end{tabular}

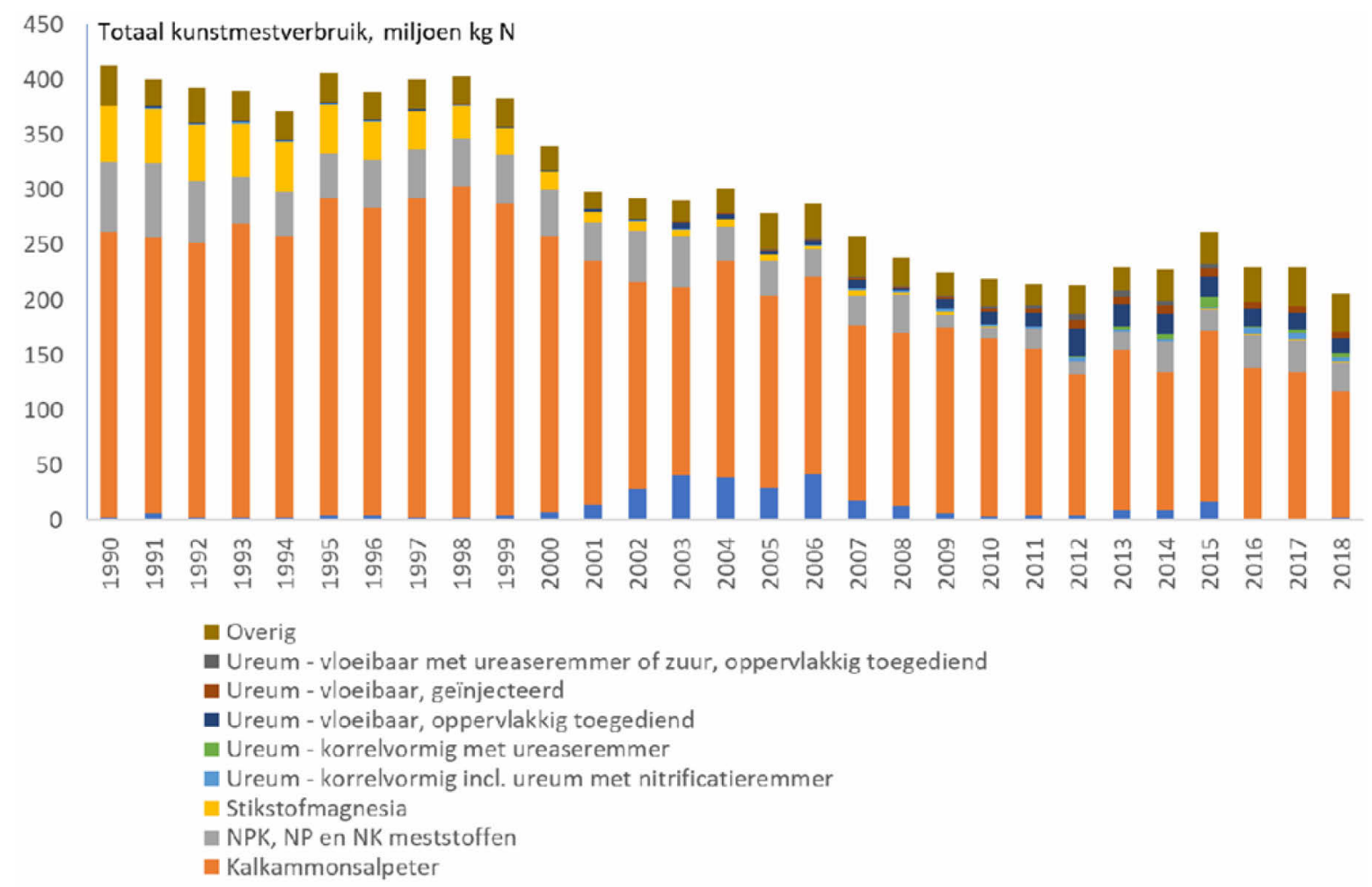

Figuur 4 Gebruik van stikstofkunstmestsoorten in de Nederlandse landbouw (Van Bruggen et al., 2021). 


\subsubsection{Toediening van kunstmestvervangers: mineralenconcentraten}

Mineralenconcentraten bevatten veel TAN en hebben een hoge $\mathrm{pH}$ (Tabel 1), waardoor het risico op ammoniakemissie hoog is. Mineralenconcentraten kennen een lagere viscositeit ten opzichte van drijfmest en infiltreren daardoor gemakkelijker in de bodem dan drijfmest; dit beperkt de ammoniakemissie. In NEMA worden vooralsnog dezelfde emissiefactoren voor mineralenconcentraten gehanteerd als die voor onbehandelde mest (gebaseerd op de hoeveelheid toegediende TAN). Omdat mineralenconcentraten meer TAN bevatten dan drijfmest, is de ammoniakemissie per eenheid totaal stikstof hoger bij mineralenconcentraten dan bij drijfmest.

In een veldexperiment van Huijsmans en $\mathrm{Hol}$ (2011) was de ammoniakemissie na zodenbemesting met mineralenconcentraat aan graan 3\% van de toegediende TAN en $12 \%$ van de toegediende TAN met een sleepvoetbemester. De ammoniakemissie van mineralenconcentraat toegediend met een zodenbemester aan grasland was $8 \%$ van de toegediende TAN. De emissiefactor in procenten van toegediende TAN van mineralenconcentraat was relatief laag ten opzichte van de gemiddelde emissiefactoren van drijfmest (Tabel 4), maar het aandeel TAN in de stikstof van mineralenconcentraat is veel hoger dan in drijfmest. $\mathrm{Er}$ is in deze studie geen vergelijking gemaakt met onbehandelde dierlijke mest en het onderzoek is slechts gedurende één jaar uitgevoerd, zodat geen harde conclusies kunnen worden getrokken over de emissie van mineralenconcentraten ten opzichte van dierlijke mest.

In een potproef van Klop et al. (2012) was de ammoniakemissie uit oppervlakkig toegediende mineralenconcentraat veel hoger dan die uit de kunstmest (kalkammonsalpeter, vloeibare ammoniumnitraat en ammoniumchloride), maar lager dan oppervlakkig toegediende varkensmest. De ammoniakemissie uit geïnjecteerde mineralenconcentraat was vergelijkbaar met die van kunstmest.

De ammoniakemissie uit oppervlakkig toegediende mineralenconcentraten was hoger dan de oppervlakkig toegediende dierlijke mest en kunstmest in een incubatieproef (Figuur 5). Injectie leidde tot een sterke reductie van ammoniakemissie. Hierbij moet worden opgemerkt dat in een incubatieproef de effectiviteit van inwerken van mest om ammoniakemissie te reduceren veel hoger is dan onder veldomstandigheden. De effectiviteit van injectie om ammoniakemissie te reduceren, was hoger bij mineralenconcentraat dan bij dierlijke mest, waarschijnlijk omdat mineralenconcentraat vloeibaarder is en dieper in de bodem infiltreert. In de praktijk wordt kunstmest oppervlakkig toegediend en mineralenconcentraten emissiearm. Emissiearme toediening van mineralenconcentraten is momenteel verplicht, omdat het nog steeds als dierlijke mest wordt beschouwd. Verwacht wordt dat emissiearme toediening verplicht zal blijven als mineralenconcentraten als kunstmestvervangers zijn erkend. KAS is de meest gebruikte kunstmest in Nederland en de ammoniakemissie uit deze meststof is relatief beperkt (Tabel 5; Figuur 5). Er zal waarschijnlijk geen groot verschil bestaan in ammoniakemissie uit oppervlakkig toegediende KAS en geïnjecteerd mineralenconcentraat.

Uit de bestaande gegevens wordt voorzichtig geconcludeerd dat de ammoniakemissie uit emissiearm toegediend mineralenconcentraat lager is dan die uit emissiearm toegediende drijfmest en waarschijnlijk vergelijkbaar is met kunstmest. Aanzuren van mineralenconcentraat leidt tot minder ammoniakemissie (Velthof en Rietra, 2019) en zou als mogelijke extra maatregel kunnen worden toegepast om ammoniakemissie uit mineralenconcentraten verder te beperken. Een alternatief is het verruimen van mogelijkheden tot blenden van NK-concentraten met bijvoorbeeld ammoniumsulfaat dat een lage $\mathrm{pH}$ waarde kent, om zo een $\mathrm{pH}$-verlaging te realiseren. Voor beide opties wordt aanbevolen om maatregelen te nemen om risico's op emissies van giftige mestgassen te beheersen en hoge zwavelgiften te voorkomen.

Bij de productie van mineralenconcentraat en bij het strippen van ammoniak uit mest wordt dikke fractie geproduceerd (Figuur 1, 2 en 3). Bij toepassing op bouwland is oppervlakkige toepassing van dikke fractie van gescheiden mest alleen toegestaan indien de mest in een direct opvolgende werkgang wordt ondergewerkt. Op grasland mag dikke fractie oppervlakkig worden aangewend. De ammoniakemissie uit oppervlakkig toegediende dikke fractie van gescheiden mest resulteert in een niet te verwaarlozen ammoniakemissie (Figuur 5). Waarschijnlijk is de ammoniakemissie van de dikke fractie van mest die gestript is op ammonium lager dan die van gescheiden mest die ontstaat bij de productie van mineralenconcentraat. De emissie uit de dikke fractie kan worden beperkt door het direct onderploegen van de dikke fractie in bouwland na toediening (wat reeds verplicht is). Op 
grasland is het niet mogelijk om de dikke fractie emissiearm toe te dienen, tenzij er weer een verpompbaar bemestingsproduct van gemaakt wordt. Indien het gebruik van dikke fractie mest in Nederland toeneemt, zal er meer ammoniakemissie in Nederland optreden. Als de dikke fractie wordt geëxporteerd naar het buitenland, dan treedt deze ammoniakemissie niet op in Nederland.
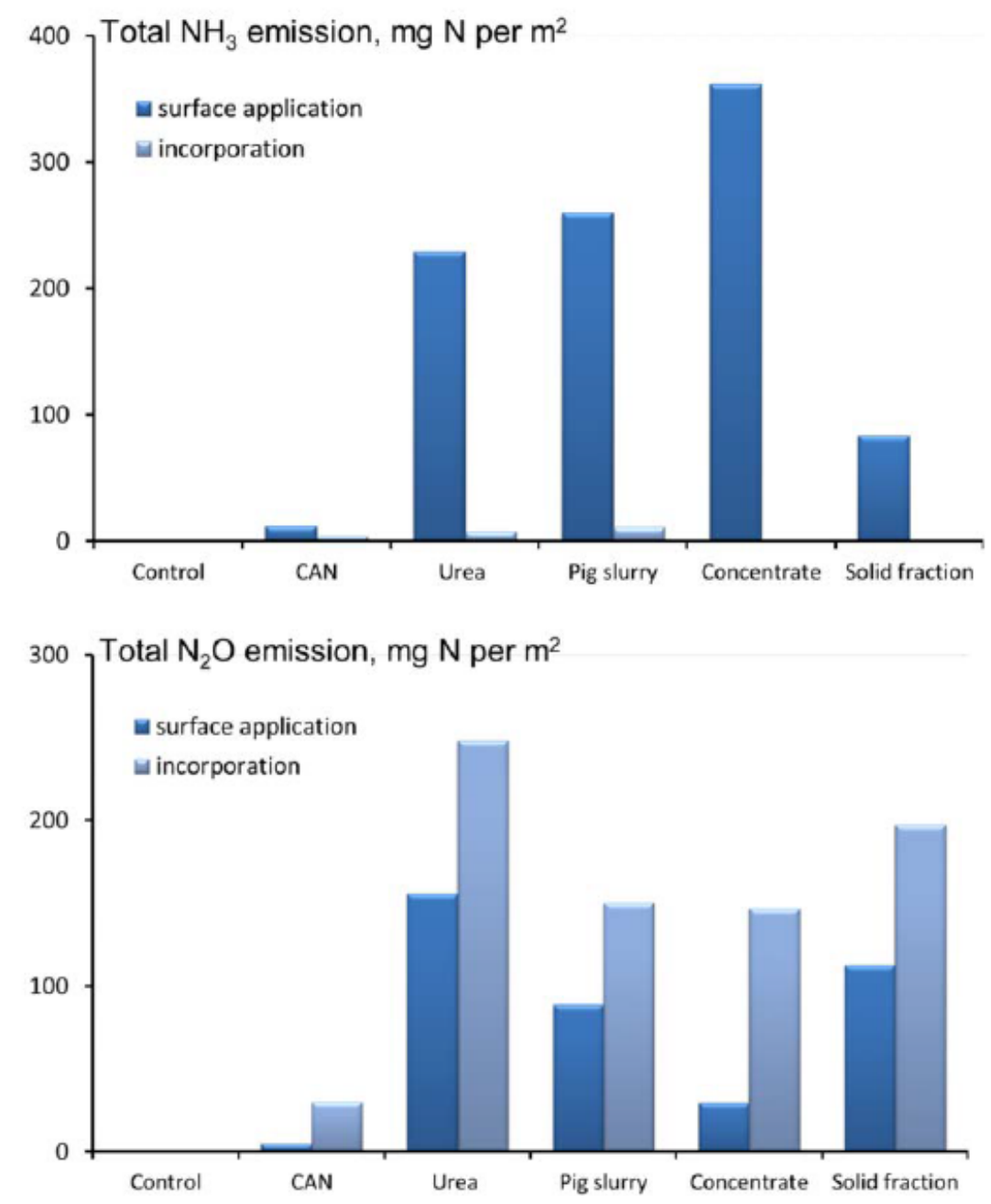

Figuur 5 Gemiddelde emissies van ammoniak (bovenste figuur) en lachgas (onderste figuur) in een incubatiestudie met grond van bouwland. De metingen vonden plaats met onbemeste grond (control) en bij bemesting met kalkammonsalpeter (CAN), ureum (urea), dunne varkensmest (pig slurry), mineralenconcentraat (concentrate) en de dikke fractie van gescheiden varkensmest die ontstaat bij de productie van mineralenconcentraat (solid fraction). Alle meststoffen werden zowel oppervlakkig toegediend als ingewerkt. De totaal N-gift was voor alle meststoffen gelijk. De emissie werd gedurende één maand bepaald (Velthof en Hummelink, 2011; Velthof et al., 2020).

\subsubsection{Toediening van kunstmestvervangers: ammoniumsulfaat en ammoniumnitraat}

De gemiddelde ammoniakemissie uit kunstmest varieert van 0 (nitraatkunstmest) tot 14,3\% voor ureum (Tabel 5). De emissiefactor voor KAS is 2,5\%. De emissiefactor in NEMA voor ammoniumsulfaat is $11,3 \%$ en die van ammoniumnitraat 5,2\%, waarbij is aangenomen dat deze meststoffen ook op kalkrijke gronden worden gebruikt (Velthof et al., 2009). Uit Tabel 6 volgt dat de ammoniakemissie bij bemesting van kalkrijke gronden veel hoger is dan bij bemesting van kalkloze en kalkarme gronden. Dit geldt met name voor ammoniumsulfaat, omdat toediening van ammoniumsulfaat aan een kalkrijke grond leidt tot vorming van gips $\left(\mathrm{CaSO}_{4}\right)$ waarbij carbonaat $\left(\mathrm{CO}_{3}\right)$ vrijkomt en het evenwicht tussen ammonium en ammoniak verschuift richting ammoniak. Het aandeel kalkrijke gronden in Nederland bedraagt zo'n $22 \%$ (Velthof et al., 2009). Vervangen van KAS door ammoniumsulfaat of ammoniumnitraat zal bij de huidige emissiefactoren in NEMA dus leiden tot een hogere ammoniakemissie. 
Anderzijds werd in een potproef van Klop et al. (2012) met een zandgrond met neutrale/lichte zure pH $(\mathrm{pH} 5,7)$ gevonden dat de ammoniakemissie uit oppervlakkig KAS iets hoger is dan uit oppervlakkig toegediende vloeibare ammoniumnitraat en ammoniumchloride. Mogelijk wordt dit veroorzaakt doordat de vloeibare kunstmest gemakkelijker in de bodem infiltreert. De ammoniakemissie was verwaarloosbaar bij injectie van alle kunstmestsoorten. NEMA maakt voor kunstmeststoffen en ammoniumsulfaat geen onderscheid in oppervlakkige aanwending versus injectie. Er is een grote onzekerheid in de emissiefactoren van kunstmeststoffen versus kunstmestvervangers, mede afhankelijk van de bodemeigenschappen en wijze van toediening.

Tabel 6 Emissiefactoren voor kunstmeststoffen berekend met de rekenregels uit Bouwman et al. (2002) (Velthof et al., 2009).

\begin{tabular}{|c|c|c|c|c|c|}
\hline \multirow[t]{2}{*}{ Meststof } & \multicolumn{2}{|c|}{ Grasland } & \multicolumn{2}{|c|}{ Akkerbouw } & \multirow{2}{*}{$\begin{array}{r}\text { Areaal gewogen } \\
\text { gemiddelde }\end{array}$} \\
\hline & $\mathrm{pH}<7.3$ & $\mathrm{pH}>7.3$ & $\mathrm{pH}<7.3$ & $\mathrm{pH}>7.3$ & \\
\hline Ammoniumsulfaat & 11 & 16 & 9 & 14 & 11 \\
\hline Ammonium nitraat & 5 & 7 & 4 & 6 & 5 \\
\hline Calcium ammonium nitraat & 2 & 4 & 2 & 3 & 3 \\
\hline Overige enkelvoudige $\mathrm{N}$-meststoffen & 4 & 6 & 4 & 6 & 4 \\
\hline $\mathrm{N}$ oplossingen & 3 & 5 & 3 & 4 & 3 \\
\hline Ammoniumfosfaten & 7 & 11 & 7 & 10 & 8 \\
\hline Overige NP meststoffen & 7 & 10 & 6 & 9 & 7 \\
\hline
\end{tabular}

\subsubsection{Effect op nationale schaal}

Scenarioanalyses op nationale schaal gaven aan dat productie en toepassing van mineralenconcentraten en dikke fractie op grote schaal geen groot effect heeft op de totale ammoniakemissie in Nederland (Lesschen et al., 2011).

\subsubsection{Conclusie}

Of de ammoniakemissie in een systeem met productie en toepassing van kunstmestvervangers verschilt van een systeem gebaseerd op drijfmest en kunstmest, hangt met name af van:

i. de duur van opslag van onbehandelde drijfmest voordat de kunstmestvervanger wordt geproduceerd;

ii. de duur en methode van de opslag van het concentraat en de dikke fractie (wel/niet afgedekt);

iii. de toepassing van de dikke fractie (wel/niet export en wel/niet direct inwerken van de dikke fractie) en;

iv. de emissie na toediening van de kunstmestvervanger. Vervangen van de kunstmest KAS door mineralenconcentraat leidt tot een hoger risico op ammoniakemissie; door diep injecteren en eventueel aanzuren kan de emissie van mineralenconcentraat sterk worden beperkt. Vervangen van KAS door ammoniumsulfaat of ammoniumnitraat zal bij de emissiefactoren die in NEMA worden gehanteerd leiden tot een hogere ammoniakemissie. Ammoniumsulfaat kan tot een hoge ammoniakemissie leiden bij toediening aan kalkrijke gronden. Het inwerken of injecteren van vloeibare ammoniumsulfaat of ammoniumnitraat kan de ammoniakemissie sterk reduceren.

Gemiddeld genomen zal de ammoniakemissie waarschijnlijk niet sterk verschillen tussen een systeem gebaseerd op productie en toepassing van kunstmestvervangers en die gebaseerd op onbehandelde drijfmest met kunstmest. Met extra eisen aan opslag (en duur van opslag) van drijfmest en dikke fractie en extra eisen aan de toediening van de kunstmestvervanger en de dikke fractie, is het waarschijnlijk mogelijk om ammoniakemissie in een systeem gebaseerd op mestverwerking tot kunstmestvervangers te reduceren ten opzichte van een systeem gebaseerd op drijfmest en kunstmest. 


\section{$4 \quad$ Lachgasemissie}

\subsection{Lachgas}

Lachgas wordt tijdens de biologische processen nitrificatie en denitrificatie gevormd. Nitrificatie is de microbiologische omzetting van ammonium $\left(\mathrm{NH}_{4}{ }^{+}\right)$naar nitraat $\left(\mathrm{NO}_{3}{ }^{-}\right)$. Voor dit proces is zuurstof nodig. Onder zuurstofarme omstandigheden wordt nitrificatie geremd en kan er lachgas $\left(\mathrm{N}_{2} \mathrm{O}\right)$ worden gevormd. Denitrificatie zorgt voor de grootste bijdrage aan lachgasvorming. Denitrificatie is de microbiologische omzetting van nitraat naar de gasvormige stikstofverbindingen luchtstikstof $\left(\mathrm{N}_{2}\right)$, lachgas en stikstofoxide $\left(\mathrm{NO}_{\mathrm{x}}\right)$. Dit proces treedt op onder zuurstofloze omstandigheden. Gemakkelijk afbreekbare organische stof is de energiebron voor denitrificerende bacteriën.

\subsection{Lachgasemissie uit de landbouw}

In Tabel 7 staat de lachgasemissie uit de landbouw weergegeven, zoals berekend met NEMA. Dit zijn de emissiecijfers die EmissieRegistratie hanteert en die Nederland internationaal rapporteert aan de Verenigde Naties (Parijs Conventie; UNFCCC).

De lachgasemissie uit de landbouw in Nederland was 18,8 kton $\mathrm{N}_{2} \mathrm{O}$ in 2018. Bodems zijn de grootste bron van lachgas (Tabel 7). De lachgasemissie door toediening van kunstmest was 3,7 kton en door toediening van dierlijke mest 4,0 kton. De emissie uit stallen en mestopslag was 1,4 kton $\mathrm{N}_{2} \mathrm{O}$ in 2019. $\mathrm{Er}$ is in de rapportages geen opsplitsing gemaakt naar dierlijke sector.

Tabel 7 Lachgasemissie uit dierlijke mest, kunstmest en overige bronnen binnen en buiten de landbouw (m/n. kg N2O per jaar) in 2019 (Van Bruggen et al., 2021).

\begin{tabular}{|c|c|}
\hline Emissiebron & 2019 \\
\hline Toediening van dierlijke mest & 4,0 \\
\hline Toediening van kunstmest & 3,7 \\
\hline Gebruik zuiveringsslib & 0,0 \\
\hline Gewasresten & 1,0 \\
\hline Graslandvernieuwing & 0,1 \\
\hline Organische bodems & 2,3 \\
\hline Indirect door atmosferische depositie & 1,6 \\
\hline
\end{tabular}

\subsection{Lachgasemissie bij toepassing van kunstmestvervangers}

\subsubsection{Inleiding}

De vraag die moet worden beantwoord, is of de lachgasemissie uit een landbouwsysteem gebaseerd op productie en toepassing van mineralenconcentraat, ammoniumsulfaat of ammoniumnitraat als kunstmestvervanger anders is dan die van de huidige situatie van onbehandelde drijfmest met kunstmest. 
Dezelfde emissiebronnen als voor ammoniak worden onderscheiden:

- Stal en mestopslag in de stal;

- Mestbewerking;

- Opslag van onbehandelde mest buiten de stal;

- Opslag van mineralenconcentraat buiten de stal;

- Toediening van meststoffen (onbehandelde mest, mineralenconcentraat, vaste fractie en kunstmest en mengsels (blends) van meststoffen).

\subsubsection{Stal en mestopslag}

In opslag van drijfmest wordt amper lachgas gevormd, omdat er geen zuurstof aanwezig is en er daardoor geen nitrificatie en denitrificatie optreden.

In vaste mestsystemen wordt wel lachgas gevormd, soms veel, omdat er wel zuurstof in de mest kan dringen. In een proef onder gecontroleerde omstandigheden naar emissies uit mestopslag was de lachgasemissie uit de vaste fractie inderdaad hoger dan uit onbehandelde mest en dunne fractie (Mosquera et al., 2010).

In NEMA wordt ervan uitgegaan dat de opslag van de vaste fractie van mest leidt tot een hogere lachgasemissie dan uit opslag van dunne mest (Tabel 3).

\subsubsection{Mestbewerking}

Er wordt geen $\mathrm{N}_{2} \mathrm{O}$-emissie berekend in NEMA voor de mest in de stal voorafgaand aan mestscheiding. Het uitgangspunt hierbij is dat de opslagduur vóór scheiden en vergisten korter is en dat de $\mathrm{N}_{2} \mathrm{O}$ emissie vooral erna plaatsvindt. Er wordt aangenomen dat tijdens de productie van mineralenconcentraten geen lachgas ontstaat (Tabel 3).

\subsubsection{Mestopslag buiten stal}

Tijdens de opslag van de dikke fractie van gescheiden mest kan lachgas ontstaan (Mosquera et al., 2010; Tabel 3).

\subsubsection{Toediening van mest en kunstmest}

In NEMA wordt onderscheid gemaakt in lachgasemissiefactoren voor kunstmest en dierlijke mest (oppervlakkig toegediend en emissiearm), voor bouwland en grasland en voor veengronden en minerale gronden (Tabel 8). De emissiefactor varieert van $0,1 \%$ voor oppervlakkige mesttoediening aan grasland op minerale gronden tot $3 \%$ voor kunstmest op veengronden. In NEMA wordt geen onderscheid gemaakt in lachgasemissiefactoren van verschillende kunstmeststoffen, maar bekend is dat nitraathoudende kunstmest een relatief hoge emissiefactor heeft op grasland ten opzichte van ammonium- en ureummeststoffen (Velthof en Rietra, 2018).

\subsubsection{Toediening van kunstmestvervangers}

Uit resultaten van een incubatiestudie werd geconcludeerd dat toediening van mineralenconcentraten aan een bodem tot een relatieve hoge lachgasemissie leidt in vergelijking met KAS (Figuur 5). De lachgasemissie uit geïnjecteerde mineralenconcentraat was iets hoger (maar niet significant) dan die uit kunstmest KAS en vloeibare ammoniumnitraat in een potproef van Klop et al. (2012).

Er zijn echter geen veldproeven uitgevoerd en in NEMA wordt voor mineralenconcentraat dezelfde lachgasemissiefactor gehanteerd als voor kunstmest (Tabel 8). Verwacht wordt dat de lachgasemissie uit ammoniumsulfaat lager en die van ammoniumnitraat vergelijkbaar is aan die van KAS (ook een ammoniumnitraat) (Velthof en Rietra, 2018). Het mengen van mineralenconcentraten met ammoniumnitraat (bijvoorbeeld door bijmenging met urean) zal waarschijnlijk leiden tot een hogere lachgasemissie, omdat het nitraat tot extra lachgasemissie kan leiden. Een vergelijkbaar effect is gevonden voor menging van urean met mest (Postma et al., 2000). 


\subsubsection{Toediening van de dikke fractie van gescheiden mest}

Toediening van de dikke fractie leidde tot een relatief hoge emissie van lachgas in een incubatieproef ten opzichte van mineralenconcentraat en onbehandelde varkensmest (Figuur 5). De organische stof in de dikke fractie, een energiebron voor denitrificerende bacteriën, speelde hier mogelijk een rol bij.

\subsubsection{Indirecte lachgasemissie}

Naast directe lachgasemissie is er ook zogenaamde indirecte lachgasemissie; dit is de lachgas die ontstaat uit vervluchtigd ammoniak ( 1,1 kton $\mathrm{N}_{2} \mathrm{O}$; Tabel 7$)$ en uitgespoeld nitraat $\left(1,1\right.$ kton $\left.\mathrm{N}_{2} \mathrm{O}\right)$. Indirecte lachgasemissie telt mee in de berekening van broeikasgasemissies (Tabel 7). Veranderingen in ammoniakemissie en nitraatuitspoeling leiden dus tot veranderingen in indirecte lachgasemissie. Zoals in de paragraaf over ammoniakemissie is aangegeven, zal de ammoniakemissie niet sterk veranderen bij grootschalige toepassing van mineralenconcentraat zonder aanvullende emissiebeperkende maatregelen. Uit onderzoek blijkt ook dat nitraatuitspoeling niet duidelijk verandert als kunstmest wordt vervangen door mineralenconcentraat (Schils et al., 2014; Schröder et al., 2013). De indirecte lachgasemissie zal dus niet sterk veranderen bij toepassing van mineralenconcentraat als kunstmestvervanger. Het ligt ook niet in de verwachting dat nitraatuitspoeling van ammoniumsulfaat en ammoniumnitraat anders is dan van KAS.

\subsubsection{Effect op nationale schaal}

In een scenarioanalyse van het effect van grootschalige toepassing van mineralenconcentraten als kunstmestvervanger in Nederland werd geconcludeerd dat toepassing van mineralenconcentraten tot geringe veranderingen in lachgasemissie leidt (Lesschen et al., 2011).

\subsubsection{Conclusie}

Toepassing van mineralenconcentraat als kunstmestvervanger zal op basis van de beschikbare informatie niet tot grote veranderingen leiden in lachgasemissie. Mogelijk neemt de lachgasemissie iets toe, omdat dikke fractie wordt opgeslagen. Hierbij moet worden opgemerkt dat er geen resultaten uit veldproeven beschikbaar zijn. Resultaten uit een incubatiestudie geven aan dat de lachgasemissie uit toegediend mineralenconcentraat vergelijkbaar of hoger is dan uit toegediend kunstmest (KAS).

Tabel 8 Gemiddelde lachgasemissiefactoren (in \% van $N$ toegediend) met standaardfouten voor KAS en dierlijke mest in Nederland (Velthof \& Mosquera, 2011). Deze factoren worden toegepast in NEMA (Van Bruggen et al., 2020). $n$ is het aantal waarnemingen.

\begin{tabular}{|c|c|c|c|c|c|}
\hline \multirow[t]{2}{*}{ Bodemtype } & \multirow[t]{2}{*}{ Meststof } & \multirow[t]{2}{*}{ Toedieningstechniek } & \multicolumn{3}{|c|}{ Landgebruik } \\
\hline & & & Bouwland & Grasland & Alle \\
\hline \multirow[t]{2}{*}{ Minerale gronden } & Kunstmest & & $0,7 \pm 0,3(n=14)$ & $0,8 \pm 0,1(n=26)$ & $0,8 \pm 0,1(n=40)$ \\
\hline & Dierlijke mest & Emissiearm & $1,3 \pm 0,3(n=21)$ & $0,3 \pm 0,1(n=7)$ & $1,1 \pm 0,2(n=28)$ \\
\hline \multirow[t]{2}{*}{ Vegaroni } & Contest & & & $3,0 \pm 0.6(n=4)$ & \\
\hline & Dierlijke mest & Emissiearm & & 1 & \\
\hline
\end{tabular}




\section{$5 \quad$ Methaanemissie}

\section{$5.1 \quad$ Methaanemissie}

Methaan wordt onder strikt zuurstofloze omstandigheden gevormd tijdens het microbiële proces methanogenese. Dit proces treedt op in mestopslagen, tijdens pensfermentatie in rundvee en in verzadigde bodems (moerassen, natte rijstteelt). In minerale gronden en in gedraineerde veengronden gebruikt voor landbouw treedt geen methaanemissie naar de atmosfeer op (Van den Pol-van Dasselaar, 1998).

\subsection{Methaanemissie uit de landbouw}

De totale methaanemissie uit de Nederlandse landbouw bedraagt 484, 1 kton $\mathrm{CH}_{4}$ in 2018 , waarvan 330,7 kton $\mathrm{CH}_{4}$ uit pensfermentatie en 154,2 kton $\mathrm{CH}_{4}$ uit mestopslagen (Tabel 9).

Tabel 9 Methaanemissie uit management dierlijke mest in de landbouw ( $\mathrm{mln} . \mathrm{kg} \mathrm{CH}_{4}$ per jaar) in 2018 (Van Bruggen et al., 2020).

\begin{tabular}{lc} 
Mestmanagement & 2018 \\
Rundvee, mestopslag & 77,4 \\
\hline Schapen, mestopslag & 0,0 \\
\hline Geiten, mestopslag & 0,1 \\
\hline Paarden, mestopslag & 0,4 \\
\hline Ezels, mestopslag & 0,0 \\
\hline Varkens, mestopslag & 56,1 \\
\hline Pluimvee, mestopslag & 2,8 \\
\hline Konijnen en pelsdieren, mestopslag & 0,6 \\
\hline Weidemest van graasdieren & 1,1 \\
\hline Mestbewerking ${ }^{1}$ & 15,8 \\
\hline Totaal mestmanagement & 154,2
\end{tabular}

1 Inclusief mestvergisting.

\subsubsection{Stal en mestopslag}

De methaanemissie uit drijfmest is hoger dan uit de dunne en dikke fractie van gescheiden mest (Mosquera et al., 2010). In NEMA wordt hier geen rekening mee gehouden. Mestbewerking kan daarnaast leiden tot een kortere opslagduur van mest in de mestkelder bij de veehouder waarmee methaanemissies beperkt kunnen worden.

\subsubsection{Mestbewerking en mestopslag}

In NEMA wordt een effect van mestbewerking op methaanemissie berekend. De uitgangspunten zijn gebaseerd op Melse en Groenestein (2016); zie Tabel 10. De methaanemissie is per vorm van mestbewerking gebaseerd op de hoeveelheid organische stof (OS) in de aangevoerde mest. Er wordt van uitgegaan dat bij mest scheiden en mest vergisten de opslagduur van mest bij de veehouder korter is, waardoor de $\mathrm{CH}_{4}$-emissie uit opgeslagen mest voorafgaand aan mest scheiden en vergisten halveert. In NEMA zijn daarnaast ook de methaanemissiefactoren voor de opslag van dikke en dunne fracties van gescheiden mest zoals afgeleid door Melse en Groenestein (2016) gehalveerd, omdat wordt uitgegaan van een kortere opslagperiode (circa drie maanden) ten opzichte van Melse en 
Groenestein, die uitgaan van zes maanden opslag. Als mestbewerking ertoe leidt dat drijfmest (hoge methaanemissie) minder lang wordt opgeslagen, zal methaanemissie afnemen.

Tabel 10 Methaanemissiefactoren voor mestbewerking ( $\mathrm{kg} \mathrm{CH4/kg} \mathrm{OS-aanvoer)} \mathrm{die} \mathrm{worden}$ toegepast in NEMA (naar Van Bruggen et al., 2021).

\begin{tabular}{lr} 
Mestbewerkingsproces & 0,0039 \\
\hline Mestscheiding en kalvergierzuivering & $0 \mathrm{H}_{4}$ \\
\hline Rundermest & 0,0086 \\
\hline Opslag dikke fractie & 0,0125 \\
\hline Opslag dunne fractie & \\
\hline Totaal & \\
\hline Vleeskalvermest: & 0,0039 \\
\hline Opslag dikke fractie & \\
\hline Varkensmest: & 0,0116 \\
\hline Opslag dikke fractie & 0,0258 \\
\hline Opslag dunne fractie & 0,0374 \\
\hline Totaal &
\end{tabular}

Productie van mineralenconcentraat

Varkensmest:

Opslag dikke fractie 0,0116

Opslag dunne fractie 0,0258

Totaal 0,0374

Mestvergisting

Rundermest 0,0055

Varkensmest 0,0069

Mest drogen en korrelen

Pluimveemest - korte vooropslag

0,0003

Mestverbranding

Pluimveemest - korte vooropslag

0,0003

\subsubsection{Toediening van meststoffen}

Er treedt geen methaanemissie op uit landbouwgronden (mineraal en veen). Toediening van meststoffen heeft geen effect op methaanemissie uit landbouwgronden.

\subsubsection{Conclusie}

Op basis van expert judgement wordt geschat dat methaanemissie uit mestopslag lager is in een systeem dat mineralenconcentraten en dikke fractie produceert dan in een systeem met drijfmest, aannemende dat drijfmest minder lang wordt opgeslagen. Dit verschil wordt groter naarmate de opslag van drijfmest minder lang duurt en de drijfmest sneller wordt gescheiden. 


\section{Effect van toepassing van mineralenconcentraten op emissies van ammoniak, lachgas en methaan}

\subsection{Inleiding}

Het CBS heeft op verzoek van de auteurs een berekening uitgevoerd met NEMA van het effect op ammoniak-, lachgas- en methaanemissies als $25 \%$ van de varkensmest in Nederland tot mineralenconcentraten wordt verwerkt en indien deze mineralenconcentraten als kunstmestvervanger worden toegepast. In Bijlage 1 staan de uitgangspunten en resultaten weergegeven.

\subsection{Uitgangspunten}

De parametrisatie van NEMA op het gebied van mestbewerking tot mineralenconcentraten staat beschreven in Tabel 3 voor ammoniak en lachgas en in Tabel 10 voor methaan. Daarnaast zijn als uitgangspunten gehanteerd (Bijlage 1 ):

- $1 \mathrm{~kg}$ mest wordt gescheiden in 0,2 kg dikke fractie en 0,8 kg dunne fractie;

- Het TAN-gehalte gemiddeld over de toegediende onbewerkte mest en het concentraat neemt ca. 4 procentpunten toe vergeleken met het TAN-gehalte van onbewerkte mest;

- De berekening is uitgevoerd met als referentie de NEMA-berekening voor 2019 (Van Bruggen et al., 2021);

- Het concentraat krijgt dezelfde verdeling over grasland en bouwland (berekend met het model INITIATOR) en wordt toegediend met dezelfde technieken als bij onbewerkte varkensmest;

- De emissiefactoren van toediening van mest worden gehanteerd (Tabel B1.6 in Bijlage 1);

- De dikke fractie leidt niet tot een toename van de export. Er wordt van uitgegaan dat de export samenhangt met de beschikbare plaatsingsruimte en dat er geen verandering optreedt in de hoeveelheid stikstof uit varkensmest die in Nederland wordt toegediend;

- Het is niet bekend of en in welke mate de acceptatie van mineralenconcentraat als kunstmestvervanger de huidige omvang van mestbewerking beïnvloedt. Vooralsnog is ervan uitgegaan dat de huidige omvang van mestbewerking niet verandert;

- De stikstof in opgeslagen varkensmest verandert door de productie van concentraat, omdat NEMA geen opslagverliezen berekent voor N2O, NO en N2 voor mest voorafgaand aan de mestbewerking. De export is door mestscheiding verlaagd met 0,6 miljoen $\mathrm{kg} \mathrm{N}$ om de toediening van varkensmest op grasland en bouwland gelijk te houden aan de referentie;

- De totale hoeveelheid stikstof die in het concentraat terechtkomt, is in mindering gebracht op het kunstmestverbruik in de landbouw, evenredig verdeeld over de kunstmestsoorten.

\subsection{Resultaten}

In Tabel 11 staan de met NEMA berekende emissies van ammoniak, methaan en lachgas uit de landbouw en sectoren buiten de landbouw waar mest uit de landbouw wordt gebruikt, weergegeven in het referentiejaar 2019 en in het scenario dat 25\% van de varkensmest wordt verwerkt tot mineralenconcentraat.

Uit de berekeningen volgt dat de ammoniakemissie uit de landbouw en andere sectoren waarin mest uit de landbouw wordt toegepast, met 0,5 kton $\mathrm{NH}_{3}$ toeneemt (emissie uit toediening en mestbewerking neemt toe, die uit kunstmest neemt af en die in stallen en mestopslag verandert niet). De lachgasemissie neemt iets af $\left(-0,1\right.$ kton $\left.\mathrm{N}_{2} \mathrm{O}\right)$ en de methaanemissie verandert niet. De methaanemissie verandert niet, omdat enkel de plaats waar de emissie optreedt verschuift van opslag voorafgaand aan mestbewerking naar de opslag van de bewerkingsproducten. 
Tabel 11 Emissies van ammoniak $\left(\mathrm{NH}_{3}\right)$, lachgas $\left(\mathrm{N}_{2} \mathrm{O}\right)$ en methaan $\left(\mathrm{CH}_{4}\right)$ naar de lucht uit de landbouw en andere sectoren (miljoen $\mathrm{kg}$ ). Berekening met NEMA.

\begin{tabular}{lccc} 
& $\begin{array}{c}\text { Referentie 2019 } \\
\mathrm{NH}_{3}\end{array}$ & $\begin{array}{c}25 \% \text { varkensmest verwerkt tot } \\
\text { mineralenconcentraat }\end{array}$ & $\begin{array}{c}\text { Verschil door productie } \\
\text { mineralenconcentraat }\end{array}$ \\
\hline stal en opslag & 112,0 & 112,5 & 0,5 \\
\hline weidegang & 59,8 & 59,8 & 0,0 \\
\hline toedienen & 1,9 & 1,9 & 0,0 \\
\hline mestbewerking & 34,9 & 35,2 & 0,3 \\
\hline kunstmest & 1,3 & 1,9 & 0,6 \\
\hline overige bronnen & 9,3 & 9,0 & $-0,4$ \\
\hline $\mathrm{N}_{2} \mathrm{O}$ & 4,8 & 4,8 & 0,0 \\
\hline $\mathrm{CH}_{4}$ & 18,8 & 18,7 & $-0,1$ \\
\hline
\end{tabular}

\subsection{Discussie}

NEMA is het model dat gebruikt wordt voor berekening van de emissies van ammoniak en broeikasgassen uit de landbouw op landelijk niveau in de EmissieRegistratie. De regionale verdeling van emissies, die als input wordt gebruikt voor de berekening van stikstofdepositie op Natura 2000-gebieden, worden geijkt aan NEMA. Verder wordt NEMA gebruikt voor de referentieramingen in het kader van de Klimaat en Energie Verkenning (KEV). Dit betekent dat als LNV mestbewerking tot kunstmestvervanger als maatregel wil inzetten in het stikstof- en klimaatdossier, NEMA geparametriseerd moet zijn voor de emissies die optreden bij productie en toepassing van kunstmestvervangers.

De methode van berekening van emissies bij mestbewerking tot mineralenconcentraten is gebaseerd op een deskstudie van Melse en Groenestein (2016; Tabel 3 en 10). Omdat mestbewerking maar een kleine bron van emissie is op nationale schaal (Tabel 2, 7 en 9), zijn er de laatste jaren geen verbeteringen gedaan in de rekenmethodiek. De relatief beperkte effecten van productie en toepassing van mineralenconcentraten op ammoniak-, lachgas- en methaanemissies worden deels veroorzaakt door de parametrisatie van NEMA. Aspecten in de rekenmethodiek van NEMA die nader geëvalueerd en beter onderbouwd moeten worden, zijn:

- De verblijftijd van onbewerkte drijfmest in de mestkelder bij mestverwerking en het effect daarvan op ammoniak-, methaan- en lachgasemissies ten opzichte van geen mestbewerking. Verwacht wordt dat de verblijftijd korter wordt door regelmatige afvoer naar een mestverwerker of bewerking op eigen bedrijf en dat daardoor de emissies in stal en de opslag van drijfmest lager worden. Mestbewerking heeft momenteel geen effect op de met NEMA berekende ammoniak- en methaanemissies uit stallen en mestopslag;

- De emissies uit opslag van mineralenconcentraten en dikke fractie van gescheiden mest. Verwacht wordt dat de methaanemissie uit de opslag van de dikke fractie van gescheiden mest lager is dan uit drijfmest, maar dit volgt niet uit berekeningen met NEMA. Dit komt omdat de huidige emissiefactoren in NEMA gebaseerd zijn op scheiding waarbij een verpompbare dikke fractie ontstaat en de emissiefactor gelijk is aan die van drijfmest. Bij scheiding tot een stapelbare dikke fractie zal de methaanemissie lager zijn, echter, dit onderscheid is niet opgenomen in NEMA;

- De emissiefactoren voor ammoniak- en lachgasemissies voor toedienen van mineralenconcentraten. In de berekeningen worden ammoniak- en lachgasemissiefactoren voor mest toegepast op mineralenconcentraten. Op basis van onderzoek wordt verwacht dat de emissiefactoren voor mineralenconcentraten bij emissiearme aanwending lager zijn dan die van dierlijke mest en vergelijkbaar zijn met kunstmest, maar er zijn onvoldoende gegevens om specifieke emissiefactoren voor mineralenconcentraten af te leiden. Ook van de andere kunstmestvervangers (vloeibare ammoniumsulfaat en ammoniumnitraat) zijn geen emissiefactoren voor lachgas en ammoniak beschikbaar;

- Effecten op de mestmarkt. Mineralenconcentraten vervangen stikstofkunstmest, maar de dikke fractie kan zowel binnen Nederland worden toegepast als worden geëxporteerd. Toepassing van de dikke fractie op grasland en/of bouwland heeft ook effect op gebruik van drijfmest en kunstmest. De toepassing van de dikke fractie kan een relatief groot effect hebben op de emissies van ammoniak en lachgas. Verwacht wordt dat de dikke fractie buiten de Nederlandse landbouw wordt afgezet, omdat de fosfaatgebruiksnorm beperkend is. 


\subsection{Conclusie}

$\mathrm{Er}$ is een berekening van het effect van productie en toepassing van mineralenconcentraten uitgevoerd met NEMA. NEMA is het model dat gebruikt wordt voor berekening van de emissies van ammoniak en broeikasgassen uit de landbouw op landelijk niveau in de EmissieRegistratie. Als LNV mestbewerking tot kunstmestvervanger als maatregel wil inzetten in het stikstof- en klimaatdossier, dan moet NEMA geparametriseerd zijn voor de emissies die optreden bij productie en toepassing van deze maatregel.

Berekeningen met NEMA van een scenario waarbij $25 \%$ van de varkensmest wordt verwerkt tot mineralenconcentraat laten beperkte effecten zien op emissies: de ammoniakemissie neemt iets toe $\left(0,5\right.$ kton $\left.\mathrm{NH}_{3}\right)$, de lachgasemissie neemt iets af $\left(-0,1\right.$ kton $\left.\mathrm{N}_{2} \mathrm{O}\right)$ en methaanemissie verandert niet.

Er zijn echter veel onzekerheden in de rekenmethodiek voor mestbewerking die momenteel in NEMA is opgenomen. Aspecten in de rekenmethodiek van NEMA die nader geëvalueerd en beter onderbouwd moeten worden, zijn de emissies uit opslag en toediening van mineralenconcentraat (en andere kunstmestvervangers) en de dikke fractie, de verblijftijd van onbewerkte mest in de stal en mestopslag en emissies bij toediening van kunstmestvervangers en de dikke fractie. Ook de toepassing van dikke fractie (export of toepassing in Nederland) kan een groot effect hebben op de emissies. Er is (experimenteel) onderzoek nodig om de rekenmethodiek van mestbewerking te verbeteren. $\mathrm{Er}$ is er veel onderzoek gepland in 2021 (EU-projecten, topsectorprojecten, projecten uit de klimaatenveloppe, BO-onderzoek en projecten uit Nationaal Kennisprogramma Stikstof), maar er is geen overzicht of al dit onderzoek alle vragen beantwoordt, bruikbare gegevens levert voor de rekenmethoden van emissies en of er extra onderzoek nodig is op onderdelen die nu niet worden onderzocht. 


\section{Energieverbruik en $\mathrm{CO}_{2}$-emissie}

\subsection{Energieverbruik}

Het Haber-Bosch-proces waarmee luchtstikstof $\left(\mathrm{N}_{2}\right)$ wordt gebonden tot stikstofkunstmest vraagt veel energie. Het energieverbruik door het Haber-Bosch proces bedraagt ongeveer $1 \%$ van de totale mondiale energieconsumptie en dit komt overeen met ongeveer $1,4 \%$ van de mondiale $\mathrm{CO}_{2}$-emissie (Industrial Technology Database, 2020).

Het Haber-Bosch-proces produceert ammoniak. Van ammoniak worden andere stikstofverbindingen gemaakt, waaronder salpeterzuur. Salpeterzuur wordt als grondstof gebruikt voor nitraathoudende stikstofmeststoffen. De efficiëntie waarmee luchtstikstof met het Haber-Bosch-proces gebonden wordt, verschilt tussen minerale meststoffabrikanten als gevolg van het gebruik van verschillende energiebronnen (aardgas, waterkracht, stoom, kolen) en verschillen in kwaliteit van energiebronnen, en procestechniek. West-Europese industrieën die minerale meststoffen produceren, hebben geïnnoveerd in procestechniek waardoor het energieverbruik fors werd verlaagd. Deze verlaging uit zich ook in een aanzienlijk lagere $\mathrm{CO}_{2}$-voetafdruk (carbon footprint ${ }^{4}$ ) voor bijvoorbeeld ammoniumnitraat $\left(3,3 \mathrm{~kg} \mathrm{CO}_{2}\right.$ equivalent per $\mathrm{kg}$ geproduceerde $\mathrm{N}$ ) of kalkammonsalpeter $(3,5 \mathrm{~kg} \mathrm{CO} 2 \mathrm{eq} / \mathrm{kg} \mathrm{N})$ van West-Europese meststoffabrikanten ten opzichte van bijvoorbeeld Chinese fabrikanten (respectievelijk 10,9 en 11,2 kg $\mathrm{CO}_{2}$ eq per kg N; Hoxba en Christensen, 2018). Tabel 12 geeft een overzicht van de $\mathrm{CO}_{2}$-voetafdruk van gangbare minerale meststoffen. De minerale meststoffenindustrie geeft met enige regelmaat nieuwe cijfers over het gebruik van energie en de $\mathrm{CO}_{2}$-voetafdruk.

Het vervangen van kunstmest door kunstmestvervangers kan leiden tot minder energiegebruik en minder $\mathrm{CO}_{2}$-emissie mits het energieverbruik van de productie en toepassing van de kunstmestvervanger lager is dan die van kunstmest. Het is bekend dat ook mestbewerking veel energie kan vragen, bijvoorbeeld bij de omgekeerde osmosetechniek die gebruikt wordt voor de productie van mineralenconcentraten. Ook de energiebron die gebruikt wordt voor het strippen van mest op ammonium bepaalt in sterke mate het verschil in energiegebruik ten opzichte van productie van regulier kunstmest. Toepassing van energie uit biogas, restwarmte of andere vormen van groene stroom verlaagt het energieverbruik van productie van meststoffen. Daarbij moet ook gerealiseerd worden dat stikstof uit mest in tegenstelling tot luchtstikstof geen oneindige bron is; het overschot aan mest bepaalt het aandeel stikstofkunstmest dat vervangen kan worden.

Gegevens over energieverbruik en over de $\mathrm{CO}_{2}$-voetdruk van kunstmestvervangers zijn in de wetenschappelijke literatuur beschikbaar in enkele overzichtsartikelen en rapportages van afgeronde EUprojecten. Deze informatie betreft meestal een bundeling van gegevens van enquêtes. Deze informatie wordt vernieuwd en aangevuld. In een aantal EU-projecten (Systemic, Fertimanure, Nutri2Cycle) en ook in het TKI-project Meerwaarde Mest en Mineralen 2 (MMM2) worden meetgegevens verzameld. De gegevens van deze projecten wachten nog op goedkeuring van de EU of zijn nog niet gepubliceerd bij publicatie van de onderhavige quickscan. Een korte literatuurstudie levert uiteenlopende ramingen voor het energieverbruik van mestverwerkingsprocessen. Deze verwerkingsprocessen zijn cascades, waarbij (trapsgewijs) processen biomassa in verschillende stadia verwerken. De keuzemogelijkheden voor het inrichten van een dergelijke cascade zijn groot. Per proces worden (sterk) verschillende gegevens over energieverbruik gegeven. De literatuur geeft data voor diverse gecascadeerde procestechnologieën waarvan onderdelen wel in Nederland worden toegepast, maar niet voor het geheel qua configuratie voor mestverwerking, waarvan het terugwinnen van nutriënten een onderdeel kan zijn. Een voorbeeld is verwerking met vergisting als onderdeel in het proces, hetgeen bij veel mestverwerkers in Nederland niet uitgevoerd wordt. Gepubliceerde gegevens geven soms het verbruik per trap van de cascade, maar vaker wordt het energieverbruik over de totale cascade gegeven. Hierbij wordt het netto energieverbruik

\footnotetext{
4 Fertilizers Europe heeft een carbon footprint calculator ontwikkeld. Deze is beschikbaar op www.fertilizerseurope.com.
} 
gegeven ten opzichte van een referentie, zoals niet verwerken of verwerken plus een toegevoegde verwerkingsstap (bv. omgekeerde osmose of ammoniakstrippen).

Joint Research Centre (JRC) heeft een indicatieve, verkennende berekening uitgevoerd naar de $\mathrm{CO}_{2}$ voetafdruk van de productie van dunne fractie van digestaat, mineralenconcentraat en ammoniumsulfaat, alle gemaakt uit digestaat van varkensdrijfmest (Huijgens et al., 2020). Tabel 13 meldt de uitkomsten van berekeningen waarbij twee transportafstanden voor afzet van het mineralenconcentraat zijn aangehouden: $25 \mathrm{~km}$ en $150 \mathrm{~km} .{ }^{5}$ Huygens et al. (2020) berekenen hierbij de extra $\mathrm{CO}_{2}$-emissie per $\mathrm{kg} \mathrm{N}$ voor opwerking van drijfmest tot een kunstmestvervanger ten opzichte van aerobe behandeling waarbij stikstof wordt omgezet in stikstofgas. Als criterium hanteren Huygens et al. (2020) dat de toename in de $\mathrm{CO}_{2}$-emissie per $\mathrm{kg} \mathrm{N}$ de $\mathrm{CO}_{2}$-voetafdruk van minerale stikstofproductie van $3 \mathrm{~kg} \mathrm{CO} 2$ per $\mathrm{kg} \mathrm{N}$ niet mag overschrijden. Op basis van deze berekeningen is bij een afstand van $25 \mathrm{~km}$ de $\mathrm{CO}_{2}$-voetafdruk gunstiger voor mineralenconcentraat of ammoniumsulfaatoplossing ten opzichte van minerale stikstofmeststof, bij $150 \mathrm{~km}$ is dat niet meer het geval. Huygens et al. (2020) gaan uit van een extra $\mathrm{CO}_{2}$-emissie ten opzichte van aerobe mestverwerking waar nitrificatie en denitrificatie onderdeel van zijn (referentiescenario). De consequentie is dat in het referentiescenario alle stikstof in de dunne fractie drijfmest verloren gaat en vervangen moet worden door minerale stikstof, hetgeen de $\mathrm{CO}_{2}$-voetafdruk van een scenario met een mineralenconcentraat in een gunstiger perspectief plaatst. Aerobe behandeling van dunne fractie mest is veelvoorkomend in Vlaanderen en Italië, maar wordt beperkt toegepast in Nederland.

In Nederland is scheiding van varkensdrijfmest gevolgd door export van dikke fractie en benutting van de dunne fractie de meest voorkomende wijze van verwerking van varkensdrijfmest. Dit maakt het uitvoeren van een vergelijkbare berekening om de $\mathrm{CO}_{2}$-voetafdruk per $\mathrm{kg} \mathrm{N}$ af te leiden gecompliceerd, omdat immers bij gebruik van dunne fractie de stikstof ook wordt benut binnen de Nederlandse landbouw, zij het onder de gebruiksnorm dierlijke mest.

Bij kunstmest zijn literatuurgegevens gebruikt die refereren aan de productie op de locatie van de fabriek (Tabel 12). Daar komt nog afstand bij. Omdat de stikstofconcentratie in kunstmest hoog is, is de bijdrage van transport relatief laag ten opzichte van kunstmestvervangers met een lager stikstofgehalte, zoals mineralenconcentraat en ammoniumsulfaat.

Tabel 12 CO2-voetafdruk bij poort fabriek (CFP at plant gate) van minerale meststoffen (Christensen et al., 2014).

\begin{tabular}{|c|c|c|c|}
\hline Meststof & Gehalte & $\begin{array}{l}\text { CFP at plant gate, kg } \\
\mathrm{CO}_{2-\mathrm{eq} / \mathrm{kg} \text { product }}\end{array}$ & $\begin{array}{c}\text { CFP at plant gate, kg } \\
\mathrm{CO}_{2}-\mathrm{eq} / \mathrm{kg} \mathrm{N}\end{array}$ \\
\hline Ammonium nitraat (AN) & $33,5 \% \mathrm{~N}$ & 1,18 & 3,5 \\
\hline Ammonium nitrosulfaat (ANS) & $26 \% \mathrm{~N}, 14 \% \mathrm{~S}$ & 0,83 & 3,2 \\
\hline Calcium nitraat (CaN) & $15.5 \% \mathrm{~N}$ & 0,68 & 4,3 \\
\hline Di-ammonium fosfaat (DAP) & $18 \% \mathrm{~N}, 46 \% \mathrm{P}_{2} \mathrm{O}_{5}$ & 0,73 & $*$ \\
\hline Ureum (UR) & $46 \% \mathrm{~N}$ & 0,91 & 1,9 \\
\hline Ureum ammonium nitraat (Urean) & $30 \% \mathrm{~N}$ & 0,82 & 2,7 \\
\hline NPK 15-15-15 (NPK) & $15 \% \mathrm{~N}, 15 \% \mathrm{P}_{2} \mathrm{O}_{5}, 15 \% \mathrm{~K}_{2} \mathrm{O}$ & 0,76 & $*$ \\
\hline
\end{tabular}

5 Huygens et al. (2020) gaan uit van aerobe mestverwerking waar nitrificatie en denitrificatie onderdeel van zijn. Deze vorm van verwerking kent Nederland bij verwerking van kalverengier, maar niet bij andere mestverwerkingsprocessen. De consequentie van dit uitgangspunt is dat een deel van de stikstof verloren gaat en vervangen moet worden door minerale stikstof, hetgeen de $\mathrm{CO}_{2}$-voetafdruk van een mineralenconcentraat in een gunstiger perspectief plaatst. 
Tabel 13 Netto $\mathrm{CO}_{2}$-voetafdruk van de productie van RENURE-meststoffen (mineralenconcentraat en ammoniumsulfaat uit digestaat) bij afzet van $25 \mathrm{~km}$ of $150 \mathrm{~kg}$ van de productielocatie (Huygens et al., 2020) t.o.v. van de referentie aerobe mestverwerking. De klimaatimpact van de productie van minerale stikstofkunstmest als referentie geldt voor een voorloperbedrijf (Huygens et al., 2020).

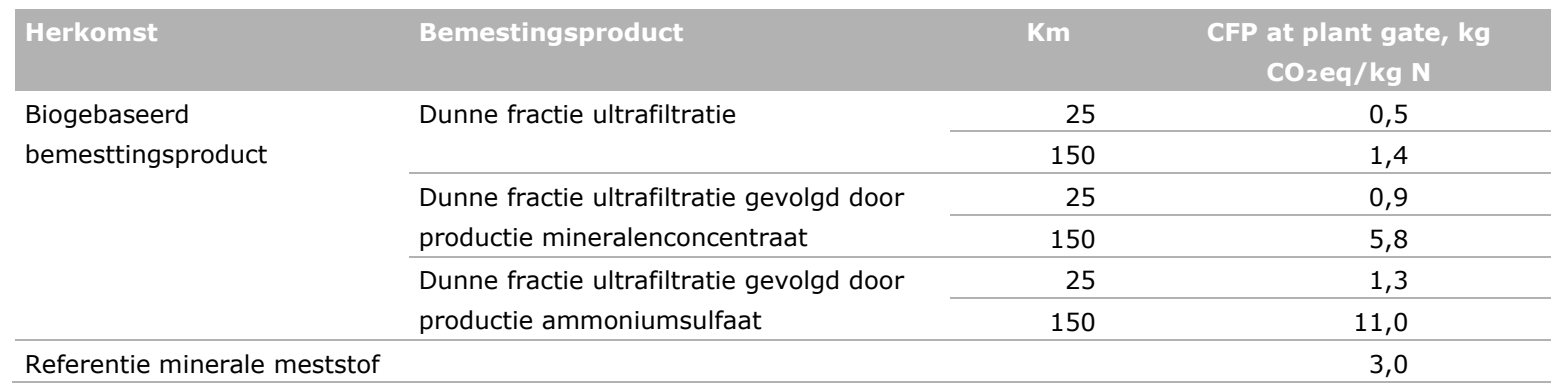

Energieverbruik per $\mathrm{m}^{3}$ ingaande mest (input) van in de praktijk gebruikte mestbewerkingsprocessen wordt gegeven in Tabel 14. Energie wordt verbruikt om verschillende processen aan te sturen en kan daardoor niet eenvoudig omgerekend worden naar kg stikstof (of een ander nutriënt) zoals dat wel mogelijk is bij de productie van minerale meststoffen. Mestbewerking beoogt volume en transport te reduceren. Incidenteel wordt wel een herleiding op een nutriënt gedaan (bijvoorbeeld bij ammoniakstrippen; $14 \mathrm{kWh}$ per $\mathrm{kg} \mathrm{N}$, Tabel 14). In de Nederlandse situatie wordt mestbewerking vergeleken met situaties waarin mest of digestaat niet wordt verwerkt of met situaties waarin mest of digestaat alleen wordt gescheiden. Er zijn grote verschillen in het gerapporteerde energieverbruik voor opwerking van mest tot mineralenconcentraat en de oorzaken achter deze verschillen zijn onduidelijk; het verkrijgen van betrouwbare gegevens vraagt om verder onderzoek waarbij praktijkgegevens worden vastgesteld inclusief condities waaronder de gegevens verkregen zijn.

Tabel 14 Energieverbruik van mestverwerkingstechnieken per $m^{3}$ drijfmest (tenzij anders aangegeven) en bij verdampingstechnieken per $m^{3}$ water.

\begin{tabular}{|c|c|c|c|}
\hline Techniek & $\begin{array}{l}\mathrm{kWh} / \mathrm{m}^{3} \\
\text { input }\end{array}$ & $\begin{array}{l}\mathrm{kWh} / \mathrm{m}^{3} \\
\text { water }\end{array}$ & Referentie \\
\hline Schroefpers & $0,1-0,5$ & & Flotats et al., 2011 \\
\hline Centrifuge/decanter & $2-4$ & & Flotats et al., 2011 \\
\hline Trommelfilter & 1 & & Flotats et al., 2011 \\
\hline Aanzuren tot $\mathrm{pH} 5,5-6$ & $1,8-3$ & & Flotats et al., 2011 \\
\hline Bekalken (liming) & $\sim 0,4$ & & Flotats et al., 2011 \\
\hline Ultrafiltratie & $0,2-1$ & & Flotats et al., 2011 \\
\hline Nanofiltratie & $0,7-1,5$ & & Flotats et al., 2011 \\
\hline Omgekeerde osmose & $1,5-10$ & & Flotats et al., 2011 \\
\hline Vacuüm drogen & $250-208$ & & Flotats et al., 2011 \\
\hline \multirow[t]{3}{*}{ Indampen, mechanische damprecompressie } & $52^{d}$ & & Melse et al., 2002 \\
\hline & & $15-40$ & Raussen \& Lootsma, 2008 \\
\hline & & 38 & Gollenbeek et al., 2020 \\
\hline Ammoniak strippen & $14 \mathrm{kWh} / \mathrm{kg} \mathrm{N}$ & & Flotats et al., 2011 \\
\hline Ammoniak strippen, elektriciteitsverbruik & $1,54-12$ & & Vaneeckhaute et al., 2017 \\
\hline Ammoniak strippen verbruik warmte & $62-69$ & & Vaneekhoute et al., 2017 \\
\hline Nitrificatie-denitrificatie & $10-20$ & & Flotats et al., 2011 \\
\hline Autotrofe anammox denitrificatie & $4-6$ & & Flotats et al., 2011 \\
\hline
\end{tabular}


Foged et al. (2011) rapporteerden over energieverbruik en $\mathrm{CO}_{2}$-voetafdruk van een aantal mestverwerkingsprocessen in Europese landen. Eén casus betrof de producent van mineralenconcentraten Kumac in Nederland. Per $\mathrm{m}^{3}$ drijfmest die werd verwerkt tot mineralenconcentraat werd 9,2 kWh per $\mathrm{m}^{3}$ verbruikt. Doordat transport van $816.000 \mathrm{~km}$ werd vermeden, waarmee $7,3 \mathrm{kWh}$ per $\mathrm{m}^{3}$ gemoeid is, werd netto $1,9 \mathrm{kWh}$ per $\mathrm{m}^{3}$ energie verbruikt met gangbaar mesttransport als referentie.

Voor een zuivere vergelijking van energieverbruik en $\mathrm{CO}$-emissies van productie en toepassing van producten wordt vaak een Life Cycle Assessment (LCA) gemaakt, waarbij het energieverbruik en de emissies in de gehele keten van productie tot toepassing worden meegenomen. Er is in 2012 een LCA gemaakt van de productie en toepassing van mineralenconcentraten (paragraaf 7.2). In 2021 staan ook andere LCA's gepland in projecten, zoals het EU-project Systemic, maar hierover waren nog geen gegevens beschikbaar. In Tabel 14 worden ook enkele andere studies beschreven waarin energiegebruik en/of $\mathrm{CO}_{2}$-emissies uit mestbewerking zijn bepaald.

\subsection{LCA van productie en toepassing mineralenconcentraten}

Uit het LCA-onderzoek van De Vries et al. $(2011$; 2012) werd geconcludeerd dat door de productie en het gebruik van mineralenconcentraat uit varkensdrijfmest ten opzichte van het gebruik van drijfmest en kunstmest geen of nauwelijks kunstmest werd vervangen binnen de systeemgrenzen van dit onderzoek. De systeemgrens liep vanaf de opslag van de drijfmest tot en met de afzet en toediening van de drijfmest en eindproducten. Afzet en toediening vond plaats via vier afzetkanalen: regio of eigen bedrijf op bouwland, regio of eigen bedrijf op grasland, buiten de regio op bouwland en export op bouwland. In de doorgerekende scenario's met mineralenconcentraten werd geen tot weinig stikstofkunstmest vervangen, maar verschoof kunstmestgebruik van binnen de regio naar buiten de regio en/of buiten Nederland. Dit omdat opwerking van dunne fractie mest tot mineralenconcentraat tot een evenredige afname leidt in het aanbod en gebruik van dunne fractie mest.

Een belangrijk aspect in deze studie was dat de stikstofwerkingscoëfficiënt van mineralenconcentraten op $80 \%$ was gesteld (en die van de dikke fractie op $41 \%$ ). Er werd dus gerekend met de werkelijke werkingscoëfficiënten en niet met de wettelijke werkingscoëfficiënt van mineralenconcentraten van $100 \%$. Door de lagere werkingscoëfficiënt ontstaat er ruimte voor aanvullend gebruik van kunstmest binnen de stikstofgebruiksnorm.

In de LCA van de Vries et al. (2011; 2012) was het effect van het vervangen van kunstmest door mineralenconcentraten op de emissies uit productie, transport en toediening van kunstmest ( $\mathrm{N}$, $\mathrm{P}$ en K) meegerekend. Emissies ten gevolge van elektriciteitsproductie, kunstmestproductie, toediening van mestproducten en transport waren gebaseerd op de Ecoinvent-database. De productie en toepassing van mineralenconcentraten uit varkensdrijfmest leidden binnen de gekozen systeemgrenzen alleen tot een lager energiegebruik en broeikasgasemissie $\left(\mathrm{CO}_{2}\right.$, lachgas en methaan) indien de mest ook werd vergist en biogas als energiebron werd gebruikt. Met name het voorkomen voor methaanemissies uit drijfmest, door een korte opslagduur en/of vergisting van de mest, gaf in de LCA-berekeningen van De Vries een voordeel in termen van broeikasgasemissies (De Vries et al., 2011).

\subsection{Strippen van ammonium uit mest}

Het ministerie van LNV heeft de auteurs van het onderhavige rapport een interne notitie verstrekt van Van Oers (2020) over GreenSwitch, een methode voor het strippen van ammonium uit mest. ${ }^{6} \mathrm{Er}$ is geen nadere analyse en evaluatie uitgevoerd naar resultaten uit deze notitie. Als voorbeeld van mogelijke productie en toepassing van kunstmestvervangers worden enkele bevindingen weergegeven

\footnotetext{
6 Marc van Oers Het GreenSwitch proces: een CO2-neutraal proces voor de productie van nitraat meststoffen. Methode voor vaststelling van emissiereductie CO2-eq., 17-06-2020.
} 
die door Van Oers (2020) zijn vermeld, maar er is geen review uitgevoerd van deze notitie. In het GreenSwitch-proces wordt ammoniumstikstof gestript uit organische mest en de opgevangen ammoniak wordt met nitrificerende bacteriën in een bioreactor naar nitraatstikstof omgezet. De ammoniakstikstof vrijkomend uit het droogproces van organische mest wordt afgevangen.

GreenSwitch-projecten worden gebouwd bij biogascentrales of andersoortige producenten die groene stroom opwekken. Met de GreenSwitch-methode wordt een vloeibare nitraatmeststof (kaliumnitraat, calciumnitraat, ammoniumnitraat en salpeterzuur) van organische oorsprong geproduceerd, geschikt voor onder andere fertigatie en bladbemesting in de glastuinbouw. Van Oers (2020) concludeert dat de emissie van broeikasgassen tot nagenoeg $0 \mathrm{~kg}$ per ton stikstof wordt verlaagd door het vervangen van conventionele processen voor productie van nitraatstikstof door nitraatstikstof geproduceerd uit meststoffen van organische oorsprong via het GreenSwitch-proces. Dit betreft de broeikasgasemissie van het productieproces van meststoffen. Effecten op de emissies van broeikasgassen uit opslag, transport en toepassing van de meststoffen zijn niet meegenomen.

\subsection{Koolstofopslag in de bodem}

Koolstofopslag in landbouwgronden is een van de maatregelen waar Nederland in het kader van het Klimaatakkoord op inzet. Of een systeem op basis van kunstmestvervangers leidt tot een andere koolstofopslag in landbouwbodems in Nederland, is afhankelijk van de toepassing van de dikke fractie die ontstaat na het scheiden van mest (deze is rijk aan organische stof). Als de dikke fractie wordt geëxporteerd omdat de fosfaat niet binnen de fosfaatgebruiksnormen uit het mestbeleid kan worden geplaatst, dan wordt er ook koolstof geëxporteerd en kan er minder koolstof aan landbouwgronden worden toegediend.

Momenteel kan ook niet alle drijfmest worden geplaatst binnen de stikstof- en fosfaatgebruiksnormen en wordt een deel geëxporteerd. De plaatsingsruimte voor de dikke fractie zal uiteindelijk bepalen of er meer of minder koolstof in landbouwgronden wordt toegediend. Als fosfaat kan worden verwijderd uit de dikke fractie zal er meer koolstof kunnen worden toegediend dan in een systeem gebaseerd op drijfmest. Er wordt geëxperimenteerd met technieken om fosfaat uit mest te halen, zodat er een fosfaatarme dikke fractie overblijft die binnen de fosfaatgebruiksnormen als bron van organische stof aan landbouwgronden kan worden toegediend (Egene et al., 2021; Schoumans et al., 2017).

\subsection{Conclusie}

Het Haber-Bosch-proces waarmee luchtstikstof $\left(\mathrm{N}_{2}\right)$ wordt gebonden tot stikstofkunstmest vraagt veel energie. West-Europese industrieën die minerale meststoffen produceren, hebben geïnnoveerd in procestechniek waardoor de $\mathrm{CO}_{2}$-voetafdruk sterk is verlaagd. Het vervangen van kunstmest door kunstmestvervangers kan leiden tot minder energiegebruik, mits het energieverbruik van de productie en toepassing van de kunstmestvervanger lager zijn dan die van kunstmest.

Het is bekend dat ook mestbewerking veel energie kan vragen, zoals de omgekeerde osmosetechniek bij de productie van mineralenconcentraten en het strippen van ammonium uit mest.

Mestverwerkingsprocessen zijn cascades waarbij (trapsgewijs) processen biomassa in verschillende stadia verwerken. Per proces worden soms sterk verschillende gegevens over energieverbruik gegeven in de literatuur, maar vaker wordt het energieverbruik over de totale cascade gegeven. Belangrijke factoren zijn het al dan niet vergisten van de mest, de transportafstand en de landbouwkundige werking van de kunstmestvervanger. Onderzoek van JRC geeft aan dat bij een afstand van $25 \mathrm{~km}$ de $\mathrm{CO}_{2}$-voetafdruk gunstiger voor mineralenconcentraat of ammoniumsulfaatoplossing is ten opzichte van minerale stikstofmeststof, maar dat dit bij $150 \mathrm{~km}$ niet meer het geval. Dit geldt voor een vergelijking met aerobe behandeling van dunne fractie mest als referentie. Om de voordelen van mestbewerking ten opzichte van gebruik of export van onbewerkte mest vast te stellen, zijn LCAstudies nodig waarbij alle stappen in de keten van stal tot toepassing worden meegenomen. 
In LCA-onderzoek van De Vries et al. $(2011 ; 2012)$ leidde productie en toepassing van mineralenconcentraten uit varkensdrijfmest binnen de gekozen systeemgrenzen alleen tot een lager energiegebruik en broeikasgasemissie indien de mest ook werd vergist.

Als de dikke fractie die wordt geproduceerd tijdens productie van kunstmestvervangers aan Nederlandse landbouwgronden wordt toegediend, kan de toegevoegde koolstof bijdragen aan het verminderen van $\mathrm{CO}_{2}$-emissies door koolstofopslag. Echter, het hoge fosfaatgehalte beperkt het gebruik van dikke fractie mest als bodemverbeteraar. Er wordt geëxperimenteerd met technieken om fosfaat uit mest te halen, zodat er een fosfaatarme dikke fractie overblijft die binnen de fosfaatgebruiksnormen als bron van organische stof aan landbouwgronden kan worden toegediend.

Er loopt onderzoek in verschillende projecten, maar deze gegevens zijn nog niet gepubliceerd en komen later dit jaar beschikbaar. Met deze resultaten kunnen het energiegebruik en de $\mathrm{CO}_{2}$-emissie van mestbewerking en toepassing van kunstmestvervangers beter worden gekwantificeerd. 


\section{Samenvatting en conclusies}

Het ministerie van LNV bereidt een subsidieregeling voor om mestverwerking te stimuleren. Gedacht wordt aan een investeringssubsidie voor de bewerking van mest - in eerste instantie gericht op varkensmest - tot verwerkte mestproducten die stikstofkunstmest kunnen vervangen. Het ministerie van LNV heeft Wageningen Research gevraagd om inzicht te geven in de effecten van de vervanging van stikstofkunstmest door producten uit verwerkte mest op de emissies van ammoniak en broeikasgassen. In een quickscan op basis van bestaand onderzoek is nagegaan wat de emissies van ammoniak en broeikasgassen zijn bij productie en toepassing van de kunstmestvervangers mineralenconcentraten en ammoniumsulfaat en ammoniumnitraat uit mest. In dit rapport wordt ingegaan op de producten uit mestbewerking, die mogelijk op termijn als stikstofkunstmestvervangers in het kader van de Nitraatrichtlijn kunnen worden toegepast: mineralenconcentraat en ammoniumsulfaat en ammoniumnitraat. Deze producten worden RENURE genoemd.

NEMA is het model dat gebruikt wordt voor de berekening van de emissies van ammoniak en broeikasgassen uit de landbouw op landelijk niveau in de EmissieRegistratie. Als LNV mestbewerking tot kunstmestvervanger als maatregel wil inzetten in het stikstof- en klimaatdossier, dan moet NEMA geparametriseerd zijn voor de emissies die optreden bij productie en toepassing van deze maatregel.

Op basis van expert judgement en bestaand onderzoek wordt geconcludeerd dat gemiddeld genomen de ammoniakemissie waarschijnlijk niet sterk zal verschillen tussen een systeem gebaseerd op drijfmest en kunstmest en een systeem gebaseerd op drijfmest en kunstmestvervangers. Belangrijk is dat de duur van de opslag van drijfmest zo kort mogelijk is en de dat de dikke fractie emissiearm wordt opgeslagen. Het mineralenconcentraat en de dikke fractie moeten emissiearm (injectie of inwerken in de bodem) worden toegediend. Een mineralenconcentraat kan eventueel aangezuurd worden, maar dit vraagt nader onderzoek naar nadelige effecten van aanzuren, waaronder een hogere zwavelgift en risico's op emissies van giftige mestgassen. Vervangen van de kunstmest kalkammonsalpeter (KAS) door ammoniumsulfaat of ammoniumnitraat zal bij de emissiefactoren die in NEMA worden gehanteerd, leiden tot een hogere ammoniakemissie. Ammoniumsulfaat leidt tot een hoge ammoniakemissie bij toediening aan kalkrijke gronden. Het inwerken of injecteren van vloeibare ammoniumsulfaat of ammoniumnitraat kan de ammoniakemissie sterk reduceren, echter, NEMA maakt voor ammoniumsulfaat en ammoniumnitraat geen onderscheid naar aanwendingsmethode.

Toepassing van mineralenconcentraat als kunstmestvervanger zal op basis van de beschikbare informatie niet tot grote veranderingen leiden in lachgasemissie. Mogelijk neemt de lachgasemissie iets toe, omdat dikke fractie wordt opgeslagen. Hierbij moet worden opgemerkt dat er geen resultaten uit veldproeven beschikbaar zijn. Resultaten uit een incubatiestudie geven aan dat de lachgasemissie uit toegediend mineralenconcentraat vergelijkbaar of hoger is dan uit toegediende KAS. Op basis van expert judgement wordt geschat dat methaanemissie uit mestopslag lager is in een systeem dat mineralenconcentraten en dikke fractie produceert dan in een systeem met drijfmest, aannemende dat drijfmest minder lang wordt opgeslagen. Dit verschil wordt groter naarmate de opslag van drijfmest minder lang duurt.

Berekeningen met NEMA van een scenario waarbij $25 \%$ van de varkensmest wordt verwerkt tot mineralenconcentraat laten beperkte effecten zien op emissies: de ammoniakemissie neemt iets toe $\left(0,5\right.$ kton $\left.\mathrm{NH}_{3}\right)$, de lachgasemissie neemt iets af $\left(-0,1\right.$ kton $\left.\mathrm{N}_{2} \mathrm{O}\right)$ en methaanemissie verandert niet.

Er zijn echter veel onzekerheden in de rekenmethodiek voor mestbewerking die momenteel in NEMA is opgenomen. Er zijn geen tot weinig meetresultaten van emissies tijdens scheiding en mestbewerking beschikbaar. Bij aanwending van mestbewerkingsproducten zoals mineralenconcentraten wordt in NEMA uitgegaan van emissiefactoren voor ammoniak en lachgas die voor dierlijke mest worden toegepast, omdat er geen emissiefactoren op basis van veldonderzoek kunnen worden afgeleid. Het geeft aan dat de onzekerheden van de berekening van effecten van gebruik van kunstmestvervangers 
met NEMA groot zijn. Als toepassing van kunstmestvervangers een belangrijke maatregel wordt in zowel het stikstof- als klimaatbeleid, dan is een evaluatie van de rekenregels en emissiefactoren van mestbewerking belangrijk. Er lopen verschillende projecten waarin onderzoek wordt uitgevoerd naar emissies uit kunstmestvervangers, zoals de EU-projecten Systemic en Fertimanure, de kunstmestvrije Achterhoek, PPS Meerwaarde Mest en Mineralen, PPS NL Next Level Mestverwaarding, het door LNV gefinancierd BO-onderzoek naar lachgasemissie en onderzoek naar ammoniakemissie uit kunstmest en mest in het kader van het Nationaal Kennisprogramma Stikstof. Resultaten van deze projecten zullen eind 2021 en de jaren daarna beschikbaar komen en zullen de inzichten in effecten van kunstmestvervangers op emissies van ammoniak en broeikasgassen verbeteren.

Het vervangen van kunstmest door kunstmestvervangers kan leiden tot minder energiegebruik, mits het energieverbruik van de productie en toepassing van de kunstmestvervanger lager zijn dan die van kunstmest. Het is bekend dat ook mestbewerking veel energie kan vragen, zoals de omgekeerde osmosetechniek bij de productie van mineralenconcentraten en het strippen van ammonium uit mest. Mestverwerkingsprocessen zijn cascades waarbij (trapsgewijs) processen biomassa in verschillende stadia verwerken. Belangrijke factoren zijn het al dan niet vergisten van de mest, de transportafstand en de landbouwkundige werking van de kunstmestvervanger. Onderzoek van JRC geeft aan dat bij een afstand van $25 \mathrm{~km}$ de $\mathrm{CO}_{2}$-voetafdruk gunstiger voor mineralenconcentraat of ammoniumsulfaatoplossing is ten opzichte van minerale stikstofmeststof, maar dat dit bij $150 \mathrm{~km}$ niet meer het geval is. In LCA-onderzoek van De Vries et al. (2011; 2012) leidden productie en toepassing van mineralenconcentraten uit varkensdrijfmest binnen de gekozen systeemgrenzen alleen tot een lager energiegebruik en broeikasgasemissie, indien de mest ook werd vergist. In deze studie was de stikstofwerkingscoëfficiënt van mineralenconcentraten op $80 \%$ gesteld (gebaseerd op proeven) en niet op de wettelijke werkingscoëfficiënt van $100 \%$. Hierdoor ontstaat er ruimte voor gebruik van kunstmest binnen de stikstofgebruiksnorm.

De wettelijke werkingscoëfficiënt van mineralenconcentraat zal waarschijnlijk $100 \%$ zijn als mineralenconcentraat als kunstmestvervanger (RENURE) is toegestaan. In potproeven was de stikstofwerking van mineralenconcentraten gemiddeld zo'n 90\% ten opzichte van KAS, maar in veldproeven was de werking lager (72-84\% voor bouwland en 54-81\% voor grasland) (Velthof et al., 2020). Dit betekent dat er meer mineralenconcentraten moeten worden toegediend dan kunstmest om eenzelfde opbrengst te realiseren of dat mineralenconcentraten een deel van de kunstmest kunnen vervangen. De stikstofwerking van ammoniumsulfaat en ammoniumnitraat is gemiddeld genomen vergelijkbaar met die van kunstmest kalkammonsalpeter.

De dikke fractie die wordt geproduceerd tijdens productie van kunstmestvervangers is door het hoge fosfaatgehalte niet geschikt als bodemverbeteraar. Er wordt geëxperimenteerd met technieken om fosfaat uit mest te halen, zodat er een fosfaatarme dikke fractie overblijft, die binnen de fosfaatgebruiksnormen als bron van organische stof aan landbouwgronden kan worden toegediend. Indien succesvol, kunnen dergelijke fosfaatarme meststoffen bij aanwending op Nederlandse landbouwgronden bijdragen aan verminderen van $\mathrm{CO}_{2}$-emissies door koolstofopslag in landbouwgronden.

Deze quickscan geeft een eerste indruk van de effecten van toepassing van kunstmestvervangers geproduceerd uit mest op ammoniak- en broeikasgasemissies. Als er aanvullende maatregelen worden genomen (zoals beperkt opslagduur en emissiearme opslag en toediening van drijfmest en producten uit mestbewerking), dan zijn er perspectieven om ammoniak- en broeikasgasemissies te beperken door het vervangen van kunstmest door kunstmestvervangers. Er zijn echter veel onzekerheden en de rekenmethoden van emissies die voor het Nederlandse beleid worden toegepast, zoals NEMA, moeten worden verbeterd. Hiervoor is experimenteel onderzoek nodig. Ook is meer onderzoek nodig naar energieverbruik tijdens mestbewerking. Zoals hierboven aangeven, is er veel onderzoek gepland in 2021 en daarna, maar er is geen overzicht of al dit onderzoek alle vragen beantwoordt of bruikbare gegevens levert voor de rekenmethoden van emissies. Geadviseerd wordt om in beeld te brengen welk onderzoek er loopt en of er extra onderzoek nodig is op onderdelen die nu niet worden onderzocht. 


\section{Literatuur}

Bouwman, A.F., L.J.M. Bouman \& N.H. Batjes (2002) Estimation of global NH3 volatilization loss from synthetic fertilizers and animal manure applied to arable lands and grasslands. Glob. Biogeochem. Cycl., vol.16, No.2, 1024

Bruggen, C. van, A. Bannink, C.M. Groenestein, J.F.M. Huijsmans, L.A. Lagerwerf, H.H. Luesink, M.B.H. Ros, G.L. Velthof, J. Vonk en T. van der Zee (2021). Emissies naar lucht uit de landbouw berekend met NEMA voor 1990-2019. Wageningen, WOT Natuur \& Milieu, WOt-technical report 203. 238 p

Christensen, B., F. Brentrup, L. Six, C. Pallière \& A. Hoxha (2014). Assessing the carbon footprint of fertilisers at production and full life cycle. Proceedings International Fertiliser Society 751.

Egene, C. E., Sigurnjak, I., Regelink, I. C., Schoumans, O. F., Adani, F., Michels, E., Sleutel, S., Tack, F. M. G., \& Meers, E. (2021). Solid fraction of separated digestate as soil improver: implications for soil fertility and carbon sequestration. Journal of Soils and Sediments, 21, 678-688.

Ehlert, P., Sigjurnak, I., Meers, E., Verbeke, M., Adani, F., Zilio, M., Tambone, F., \& Schoumans, O. (2019). Nitrogen fertilising products based on manure and organic residues: supporting literature of the SYSTEMIC factsheets. Rapport. Wageningen Environmental Research. https://doi.org/10.18174/506912

Ehlert, P.A.I., J. van der Lippe, J. (2019) Toetsing van de groene weide meststof in de praktijk: Demovelden van de gebiedsgerichte pilot Kunstmestvrije Achterhoek. Wageningen Environmental Research rapport 3304. https://doi.org/https://doi.org/10.18174/532700

Ehlert, P.A.I. (2020) Agronomic efficacy of nitrogen biobased fertilising products of co-digested pig manure. Wageningen Environmental Research, rapport 3303. https://doi.org/https://doi.org/10.18174/532699

Flotats, Xavier, Henning Lyngsø Foged, August Bonmati Blasi, Jordi Palatsi, Albert Magri and Karl Martin Schelde (2011). Manure processing technologies. Technical Report No. II concerning "Manure Processing Activities in Europe" to the European Commission, Directorate-General Environment. 184 pp.

Foged, Henning Lyngsø, Xavier Flotats, August Bonmati Blasi, Karl Martin Schelde, Jordi Palatsi, Albert Magri and Zivko Juznik (2011) Assessment of economic feasibility and environmental performance of manure processing technologies. Technical Report No. IV to the European Commission, Directorate-General Environment. 130 pp.

Gastel, J.P.B.F. van \& J.G.M. Thelosen (1995). Vermindering van het volume van zeugenmest door middel van omgekeerde osmose. Reduction of the volume of sow slurry with reverse osmosis. Praktijkonderzoek Varkenshouderij. https://edepot.wur.nl/26794

Gollenbeek L.R., J.P.B.F. van Gastel, P.J.T.H. Bussmann, R.W. Melse, \& N. Verdoes (2020). Verkenning mogelijke mestverwerkingsroutes en duurzaamheidsaspecten; NL Next Level Mestverwaarden WP2. Wageningen Livestock Research, Rapport 1270.

Hoeksma, P. and de Buisonjé, F. (2020). Mineral Concentrates from Membrane Filtration. In Biorefinery of Inorganics (eds E. Meers, G. Velthof, E. Michels and R. Rietra). https://doi.org/10.1002/9781118921487.ch4-2 
Hoeksma, P., H. Schmitt, F. de Buisonjé, H. Pishgar Komleh and P. Ehlert (2021) Composition of mineral concentrates. Results of monitoring installations of the pilot mineral concentrate. Wageningen Livestock Research, Report 1295.

Huijsmans J.F.M. en J.M.G. Hol (2011) Ammoniakemissie bij toediening van mineralenconcentraat op beteeld bouwland en grasland. Plant Research International 398, Wageningen, 26 p.

Huygens D, Orveillon G, Lugato E, Tavazzi S, Comero S, Jones A, Gawlik B, Saveyn HGM (2020), Technical proposals for the safe use of processed manure above the threshold established for Nitrate Vulnerable Zones by the Nitrates Directive (91/676/EEC), EUR 30363 EN, Publications Office of the European Union, Luxembourg, 2020, doi:10.2760/373351, JRC121636.

Industrial Technology Data-base: http://www.iipinetwork.org/wp-content/Ietd/content/ammonia.html

Klop, G., Velthof, G. L., \& van Groenigen, J. W. (2012). Application technique affects the potential of mineral concentrates from livestock manure to replace inorganic nitrogen fertilizer. Soil Use and Management, 28(4), 468-477.

Lesschen, J. P., Staritsky, I. G., \& Velthof, G. L. (2011). Verkenning grootschalige toepassing van mineralenconcentraten in Nederland: effecten op nutriëntenstromen en emissies. Alterra-rapport; No. 2247.

Melse, R.W., \& C.M. Groenestein (2016) Emissiefactoren mestbewerking. Inschatting van emissiefactoren van ammoniak, methaan en lachgas uit mestbewerking. Wageningen, Wageningen UR (University \& Research centre) Livestock Research, Livestock Research Rapport 962.

Mosquera Losada, J., Schils, R. L. M., Groenestein, C. M., Hoeksma, P., Velthof, G. L., \& Hummelink, E. W. J. (2010). Emissies van lachgas, methaan en ammoniak uit mest na scheiding = Emissions of nitrous oxide, methane and ammonia from manure after separation. Rapport Livestock Research 427, Wageningen UR.

Oers, M. Van. (2020) Het GreenSwitch proces: een $\mathrm{CO}_{2}$ neutraal proces voor de productie van nitraat meststoffen. Methode voor vaststelling van emissiereductie CO2-eq., 17-06-2020

Pol-van Dasselaar, A. van den (1998) Methane emissions from grasslands. PhD thesis Wageningen University.

Postma, R., Velthof, G. L., \& Oenema, O. (2000). Patterns of gaseous nitrogen losses from cattle slurries enriched with urea of urea ammonium nitrate. Meststoffen: Dutch/English annual on fertilizers and fertilization, 74-81.

Raussen, T., \& A. Lootsma (2008). Verfahren der Gärrestaufbereitung. In Kern, Raussen, Wagner (Hrsg.): Weiterentwicklung der biologischen Abfallbehandlung II. HeRo Schriftenreihe, Band 3, S. 259-278.

Schils, R. L. M., Geerts, R. H. E. M., Oenema, J., Verloop, J., Assinck, F. B. T., \& Velthof, G. L. (2014). Effect van gebruik mineralenconcentraat op nitraatuitspoeling: verkennend onderzoek in het kader van de Pilot Mineralenconcentraten. (Alterra-rapport; No. 2570). Alterra, Wageningen-UR.

Schoumans, O. F., Ehlert, P. A. I., Regelink, I. C., Nelemans, J. A., Noij, I. G. A. M., van Tintelen, W., \& Rulkens, W. H. (2017). Chemical phosphorus recovery from animal manure and digestate: Laboratory and pilot experiments. Research rapport No. 2849, Wageningen Environmental Research.

Schröder, J.J., de Visser, W., Assinck, F.B.T. and Velthof, G.L. (2013), Effects of short-term nitrogen supply from livestock manures and cover crops on silage maize production and nitrate leaching. Soil Use Manage, 29: 151-160. 
Vaneeckhaute, C., V. Lebuf, E. Michels, E. Belia, P.A. Vanrolleghem, F.M.G. Tack \& E. Meers (2017). Nutrient recovery from digestate: Systematic technology review and product classification. Waste Biomass Valor, 8: 21-40.

VCM (2020) Flemish biobased fertilizers recovered from manure complying to the RENURE-criteria. December 2020. Vlaams Coördinatie Centrum Mestverwerking. https://cdn.digisecure.be/vcm/202133153149721_20210208-renure-informationdocument.pdf

Velthof, G. L., \& Mosquera Losada, J. (2011). Calculation of nitrous oxide emission from agriculture in the Netherlands: update of emission factors and leaching fraction. Report; No. 2151. Alterra, Wageningen UR.

Velthof, G. L., \& Hummelink, E. W. J. (2011). Ammoniak- en lachgasemissie na toediening van mineralenconcentraten: resultaten van laboratoriumproeven in het kader van de Pilot Mineralenconcentraten. Rapport No. 2180, Alterra, Wageningen UR.

Velthof, G.L., C. van Bruggen, C.M. Groenestein, B.J. de Haan, M.W. Hoogeveen en J.F.M. Huijsmans (2009). Methodiek voor berekening van ammoniakemissie uit de landbouw in Nederland, Wageningen, Wettelijke Onderzoekstaken Natuur \& Milieu, WOt-rapport 70.

Velthof, G.L. (20150. Mineral concentrate from processed manure as fertiliser. Wageningen, Alterra Wageningen UR, Alterra report 2650. 36 pp.

Velthof, G.L. en Rietra, R.P.J.J. (2019). Nitrogen Use Efficiency and Gaseous Nitrogen Losses from the Concentrated Liquid Fraction of Pig Slurries. International Journal of Agronomy, vol. 2019, Article ID 9283106, https://doi.org/10.1155/2019/9283106

Velthof, G. L., Ehlert, P. A. I., Schroder, J. J., \& Curth-van Middelkoop, J. C. (2020). Application of Mineral Concentrates from Processed Manure. In E. Meers, G. Velthof, E. Michels, \& R. Rietra (Eds.), Biorefinery of Inorganics: Recovering Mineral Nutrients from Biomass and Organic Waste (pp. 260)

Velthof, G. L., \& Rietra, R. P. J. J. (2018). Nitrous oxide emission from agricultural soils. (Wageningen Environmental Research report; No. 2921). Wageningen Environmental Research.

Vries, de, J. W., Hoeksma, P., \& Groenestein, C. M. (2011). LevensCyclusAnalyse (LCA) pilot mineralenconcentraten = Life Cycle Assessment (LCA) mineral concentrates pilot. Rapport; No. 480). Wageningen UR Livestock Research.

Vries de, J.W., Groenestein, C.M. en De Boer, I.J.M. (2012) Environmental consequences of processing manure to produce mineral fertilizer and bio-energy. Journal of Environmental Management, 102, $173-183$. 


\section{Bijlage 1 Berekening met NEMA}

\section{Cor van Bruggen (CBS), 23 maart 2021}

\section{Vraag van WENR aan CBS}

Is het mogelijk om met NEMA een berekening uit te voeren naar het effect van mestbewerking op emissies van ammoniak, methaan en lachgas? Wat is het effect als $25 \%$ van de geproduceerde varkensmest tot mineralenconcentraat wordt verwerkt en dat dit mineralenconcentraat kunstmest vervangt? Er moet worden uitgegaan van $100 \%$ stikstofwerking, dus $1 \mathrm{~kg} \mathrm{~N}$ in mineralenconcentraat vervangt $1 \mathrm{~kg} \mathrm{~N}$ in kunstmest. In Tabel B1.1 wordt de samenstelling van mineralenconcentraat van varkensmest gegeven.

Tabel B1.1 Gemiddelde samenstelling van onbehandelde varkensdrijfmest, dikke fractie en mineralenconcentraat van varkensmest (Hoeksma et al., 20211). Input = drijfmest; Solid fraction = dikke fractie; RO-input = dunne fractie die de omgekeerde osmose in gaat; $R O$-concentraat = mineralen concentraat: dunne fractie die uit de omgekeerde osmose komt; RO-permeaat = het water uit de omgekeerde osmose.

\begin{tabular}{|c|c|c|c|c|c|c|}
\hline & & Input & Solid fraction & RO-input & RO-concentrate & RO Permeaat \\
\hline parameter & Unit & Mean & Mean & Mean & Mean & Mean \\
\hline TS & $\mathrm{g} / \mathrm{kg}$ & 61 & 283 & 16 & 35 & NA \\
\hline VS & $\mathrm{g} / \mathrm{kg} \mathrm{dm}$ & 654 & 753 & 319 & 296 & NA \\
\hline C-total & $\mathrm{g} / \mathrm{kg} \mathrm{dm}$ & 340 & 378 & 127 & 123 & 136 \\
\hline TOC & $\mathrm{mg} / \mathrm{kg}$ & 2343 & 2776 & 1463 & 3357 & 16 \\
\hline Total-N & $\mathrm{mg} / \mathrm{kg}$ & 4687 & 11972 & 2872 & 6356 & 62 \\
\hline TAN & $\mathrm{mg} / \mathrm{kg}$ & 2763 & 2589 & 2438 & 5439 & 59 \\
\hline $\mathrm{P}$ & $\mathrm{mg} / \mathrm{kg}$ & 1311 & 7140 & 52 & 72 & 3.9 \\
\hline $\mathrm{P}-\mathrm{PO}_{4}$ & $\mathrm{mg} / \mathrm{kg}$ & 198 & 351 & 28 & 40 & 0.71 \\
\hline K & $\mathrm{mg} / \mathrm{kg}$ & 3489 & 3846 & 3074 & 7183 & 11 \\
\hline EC & $\mathrm{mS}$ & 24 & 4.2 & 28 & 56 & 2.7 \\
\hline $\mathrm{pH}$ & & 7.8 & 8.4 & 7.8 & 7.9 & 7.5 \\
\hline $\mathrm{NO}_{2}-\mathrm{N}+\mathrm{NO}_{3}-\mathrm{N}$ & $\mathrm{mg} / \mathrm{kg}$ & 0.26 & 8.4 & 1.4 & 4.4 & 0.29 \\
\hline $\mathrm{Ca}$ & $\mathrm{mg} / \mathrm{kg}$ & 1837 & 9113 & 149 & 214 & 6.9 \\
\hline $\mathrm{Mg}$ & $\mathrm{mg} / \mathrm{kg}$ & 921 & 4546 & 129 & 251 & 1.1 \\
\hline $\mathrm{Na}$ & $\mathrm{mg} / \mathrm{kg}$ & 982 & 914 & 952 & 2169 & 17 \\
\hline$S$ & $\mathrm{mg} / \mathrm{kg}$ & 748 & 4089 & 1692 & 3623 & 27 \\
\hline $\mathrm{Cl}-$ & $\mathrm{mg} / \mathrm{kg}$ & 1570 & 1023 & 1591 & 3527 & 22 \\
\hline
\end{tabular}

\section{Uitwerking ( $25 \%$ van de varkensmest wordt verwerkt tot mineralenconcentraat)}

Uit de gegevens in de bovenstaande Tabel moet eerst berekend worden hoeveel stikstof en fosfaat uit de onbewerkte mest uiteindelijk in de dikke fractie en in het concentraat terechtkomen. Uit de concentraties van $\mathrm{N}$ in input, dikke fractie en RO-input valt af te leiden dat elke $\mathrm{kg}$ mest gescheiden wordt in ongeveer $0,2 \mathrm{~kg}$ dikke fractie en 0,8 kg RO-input: $11972 \mathrm{x}$ volume solid $+2872 \mathrm{x}$ $(1$ - volume solid $)=4687$. Hieruit volgt dat volume solid $0,2 \mathrm{~kg}$ is en volume RO-input $0,8 \mathrm{~kg}$.

Van de $\mathrm{N}$ in de onbewerkte mest komt dus $2872 \times 0,8=2298 \mathrm{~N}$ in de RO-input en $11972 \times 0,2=$ $2394 \mathrm{~N}$ in de dikke fractie. Dus 49\% (2298/4687) van de N in de onbewerkte mest komt terecht in de RO-input. Op dezelfde manier kan afgeleid worden hoeveel van de $\mathrm{N}$ in de RO-input in het concentraat (99\%) en hoeveel in het permeaat (1\%) terechtkomen. Gezien deze verdeling wordt er gemakshalve van uitgegaan dat alle $\mathrm{N}$ in RO-input in het concentraat terechtkomt. Op dezelfde manier is berekend dat $97 \%$ van de $\mathrm{P}_{2} \mathrm{O}_{5}$ in de onbewerkte mest in de dikke fractie terechtkomt en $3 \%$ in de RO-input. 
De verdeling van de TAN kan op basis van bovenstaande tabel niet worden berekend: de TANconcentratie in dikke fractie en in RO-input zijn beide lager dan in de onbewerkte mest. Om toch rekening te houden met het TAN-gehalte van concentraat, is de TAN in de toegediende mest (onbewerkte mest + concentraat) als volgt berekend:

TAN toegediende varkensmest $=($ Deel onbewerkte mest $\mathrm{x}$ TAN onbewerkte mest + Deel concentraat $\mathrm{x}$ TAN concentraat).

Hierin is:

Deel onbewerkte mest $=75 \%$ van de varkensmest;

TAN onbewerkte mest in NEMA: voor vleesvarkensmest is dit 58,5\% en voor fokvarkensmest $60,0 \%$; Deel concentraat $=25 \%$ van de varkensmest $\mathrm{x}$ het deel van de $\mathrm{N}$ dat in het concentraat terechtkomt $(49 \%)=12,3 \%$;

TAN concentraat $=86 \%$ volgens bovenstaande tabel;

De gemiddelde TAN neemt ca. 4 procentpunten toe vergeleken met de TAN van onbewerkte mest.

In de berekening is verder uitgegaan van het volgende:

- De berekening is uitgevoerd met als referentie de NEMA-berekening voor 2019 (Van Bruggen et al., in voorbereiding);

- Het concentraat krijgt dezelfde verdeling over grasland en bouwland (berekend met INITIATOR) en wordt toegediend met dezelfde technieken als bij onbewerkte varkensmest:

- vleesvarkensmest: grasland 14,5\%, onbeteeld bouwland $72,4 \%$, beteeld bouwland $13,1 \%$;

- fokvarkensmest; grasland 15,4\%, onbeteeld bouwland $71,8 \%$, beteeld bouwland $12,8 \%$.

- De emissiefactoren staan in Tabel B1.6 weergegeven;

- De dikke fractie leidt niet tot een toename van de export. Er wordt van uitgegaan dat de export samenhangt met de beschikbare plaatsingsruimte en dat er geen verandering optreedt in de hoeveelheid $\mathrm{N}$ uit varkensmest die in Nederland wordt toegediend;

- Het is niet bekend of en in welke mate de mestscheiding voor de productie van mineralenconcentraat de huidige omvang van mestscheiding beïnvloedt. Vooralsnog is ervan uitgegaan dat de huidige omvang van mestscheiding niet verandert;

- De totale $\mathrm{N}$ die in het concentraat terechtkomt, is in mindering gebracht op het kunstmestverbruik in de landbouw, evenredig verdeeld over de kunstmestsoorten.

In Tabel B1.2 staan de hoeveelheden $\mathrm{N}$ en $\mathrm{P}_{2} \mathrm{O}_{5}$ in de onbewerkte varkensmest voor de productie tot mineralenconcentraat in 2019 (de referentie) en voor de situatie waarin $25 \%$ van de varkensmest wordt verwerkt tot mineralenconcentraat. Ook is de hoeveelheid $\mathrm{N}$ gegeven in het geproduceerde concentraat (49\% van de $\mathrm{N}$ in onbewerkte mest).

Tabel B1.2 Productie mineralenconcentraat uit varkensmest (miljoen kg).

\begin{tabular}{|c|c|c|c|}
\hline & $\begin{array}{l}\text { Referentie } \\
2019\end{array}$ & $\begin{array}{l}25 \% \text { varkensmest verwerkt } \\
\text { tot mineralen-concentraat }\end{array}$ & $\begin{array}{c}\text { Verschil door } \\
\text { productie mineralen } \\
\text { concentraat }\end{array}$ \\
\hline $\begin{array}{l}\mathrm{N} \text { in onbewerkte fokvarkensmest } \\
\text { voor productie concentraat }\end{array}$ & 0,7 & 5,8 & 5,1 \\
\hline $\begin{array}{l}\text { P2O5 in onbewerkte vleesvarkensmest } \\
\text { voor productie concentraat }\end{array}$ & 1,8 & 5,8 & 4,1 \\
\hline $\begin{array}{l}\text { P2O5 in onbewerkte fokvarkensmest } \\
\text { voor productie concentraat }\end{array}$ & 0,5 & 3,2 & 2,7 \\
\hline
\end{tabular}

In Tabel B1.3 staan de veranderingen van de hoeveelheid $\mathrm{N}$ in de opgeslagen mest, in de afzet buiten de landbouw en het $\mathrm{N}$-verlies door de productie van mineralenconcentraat ten opzichte van de 
referentie (2019). De $\mathrm{N}$ in opgeslagen varkensmest verandert door de productie van concentraat, omdat NEMA geen opslagverliezen berekent voor $\mathrm{N}_{2} \mathrm{O}$, $\mathrm{NO}$ en $\mathrm{N}_{2}$ voor mest voorafgaand aan de mestbewerking. De export van $\mathrm{N}$ door mestscheiding is verlaagd met 0,6 miljoen $\mathrm{kg}$ om de toediening van varkensmest op grasland en bouwland gelijk te houden aan de referentie (54,2 miljoen $\mathrm{kg} \mathrm{N}$ in 2019).

Tabel B1.3 $N$ in opgeslagen varkensmest, $N$-onttrekking aan de landbouw en $N$ in toegediende varkensmest (miljoen $\mathrm{kg} \mathrm{N}$ ).

\begin{tabular}{lccc} 
& $\begin{array}{c}\text { Referentie } \\
\text { N in opgeslagen varkensmest }\end{array}$ & $\begin{array}{c}25 \% \text { varkens-mest verwerkt } \\
\text { tot mineralenconcentrat }\end{array}$ & $\begin{array}{c}\text { Verschil door productie } \\
\text { mineralenconcentraat }\end{array}$ \\
\hline $\begin{array}{l}\text { N-hobbybedrijven, particulieren, } \\
\text { natuurterreinen varkensmest }\end{array}$ & 2,2 & 73,3 & 0,4 \\
\hline N-export onbewerkte varkensmest & 8,2 & 2,2 & 0,0 \\
\hline N-export mestscheiding varkensmest & 6,7 & 8,2 & 0,0 \\
\hline $\begin{array}{l}\text { N-verlies varkensmest mestbewerking } \\
\text { Totaal N-varkensmest onttrokken aan }\end{array}$ & 1,7 & 6,1 & $-0,6$ \\
de landbouw & 18,7 & 19,1 & 1,0 \\
\hline
\end{tabular}

In Tabel B1.4 staat de verandering in het kunstmestgebruik door de productie van mineralenconcentraat ten opzichte van de referentie 2019. In totaal wordt 8,8 miljoen $\mathrm{kg} \mathrm{N}$ bespaard op kunstmest (zie Tabel B1.2), evenredig verdeeld over de kunstmestsoorten.

In Tabel B1.5 staan de effecten van de productie van mineralenconcentraat op de emissies naar lucht, met de kanttekening dat de effecten sterk afhankelijk zijn van de gekozen uitgangspunten. De $\mathrm{NH}_{3}-$ emissie bij mest toedienen neemt toe door het relatief hoge TAN-gehalte van mineralenconcentraat. De $\mathrm{NH}_{3}$-emissie door mestscheiding neemt eveneens toe, aangezien ervan uitgegaan wordt dat de mestscheiding voor de productie van mineralenconcentraat niet in de plaats komt van de mestscheiding die al plaatsvindt (Tabel B1.3).

Vervanging van kunstmest door mineralenconcentraat levert een besparing van 0,4 $\mathrm{mln}$. $\mathrm{kg} \mathrm{NH}_{3}$.

$\mathrm{N}_{2} \mathrm{O}$ - en NO-emissies dalen eveneens door de besparing op kunstmest. De $\mathrm{CH}_{4}$-emissie verandert niet, omdat enkel de plaats waar de emissie optreedt verschuift van opslag voorafgaand aan mestbewerking naar de opslag van de bewerkingsproducten. De emissie van NMVOS (Vluchtige organische stoffen, exclusief methaan) is afhankelijk van de verhouding van de $\mathrm{NH}_{3}$-emissie bij toedienen en de $\mathrm{NH}_{3}$-emissie uit stallen en neemt daardoor iets toe. De $\mathrm{CO}_{2}$-emissie daalt door de verminderde afzet van ureummeststof (Tabel B1.4). 
Tabel B1.4 Verandering in kunstmestgebruik door productie mineralenconcentraat uit varkensmest (miljoen $\mathrm{kg} \mathrm{N}$ ).

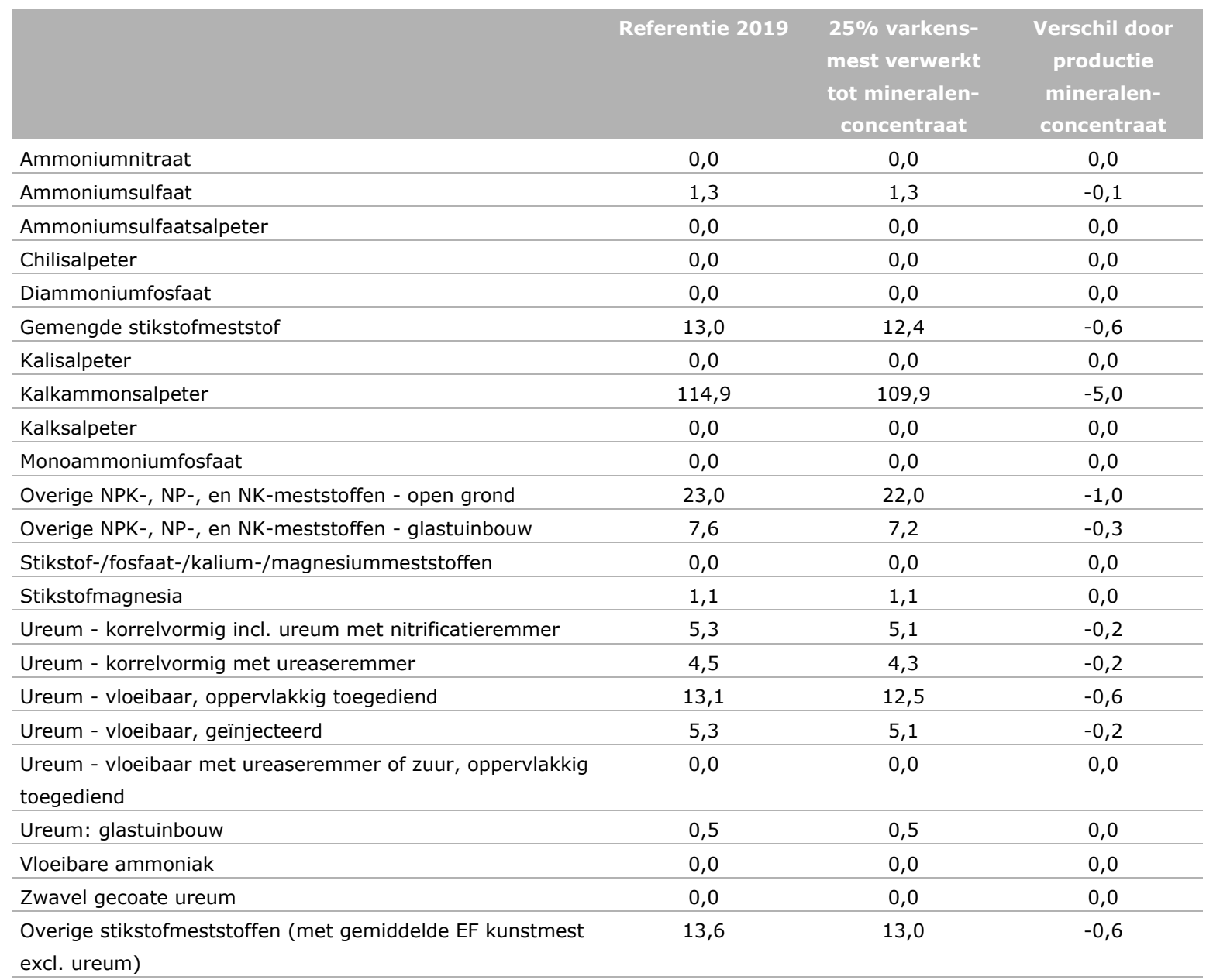

\section{Totale afzet w.v.}

\begin{tabular}{lccc}
\hline land- en tuinbouw & 203,2 & 194,4 & $-8,8$ \\
\hline hobbybedrijven (veronderstellen we constant) & 8,7 & 8,7 & 0,0 \\
\hline particulieren e.d. (veronderstellen we constant) & 5,0 & 5,0 & 0,0 \\
\hline & & & \\
\hline Totale afzet & 216,9 & 208,1 & $-8,8$ \\
\hline
\end{tabular}


Tabel B1.5 Emissies naar lucht uit de landbouw (miljoen kg).

\begin{tabular}{|c|c|c|c|}
\hline & Referentie 2019 & $\begin{array}{l}25 \% \text { varkens- } \\
\text { mest verwerkt } \\
\text { tot mineralen- } \\
\text { concentraat }\end{array}$ & $\begin{array}{l}\text { Verschil door } \\
\text { productie } \\
\text { mineralen- } \\
\text { concentraat }\end{array}$ \\
\hline $\mathrm{NH}_{3}$ & 112,0 & 112,5 & 0,5 \\
\hline stal en opslag & 59,8 & 59,8 & 0,0 \\
\hline toedienen & 34,9 & 35,2 & 0,3 \\
\hline mestbewerking & 1,3 & 1,9 & 0,6 \\
\hline kunstmest & 9,3 & 9,0 & $-0,4$ \\
\hline overige bronnen & 4,8 & 4,8 & 0,0 \\
\hline NMVOS & 87,8 & 87,9 & 0,1 \\
\hline $\mathrm{CO}_{2}$ & 80,1 & 78,2 & $-2,0$ \\
\hline kalkmeststoffen & 34,9 & 34,9 & 0,0 \\
\hline ureum & 45,2 & 43,2 & $-2,0$ \\
\hline
\end{tabular}

Tabel B1.6 Implementatiegraden (\% mest) en emissiefactoren voor $\mathrm{NH}_{3}$ bij toedienen van mest (\% van TAN).

\begin{tabular}{|c|c|c|}
\hline & Implementatigraden & Emissiefactor \\
\hline \multicolumn{3}{|l|}{ Grasland - drijfmest } \\
\hline zodenbemester & $83,7 \%$ & $17,0 \%$ \\
\hline sleepvoeten en sleepslangen & $14,5 \%$ & $17,0 \%$ \\
\hline bovengronds & $1,8 \%$ & $68,0 \%$ \\
\hline \multicolumn{3}{|l|}{ Onbeteeld bouwland - drijfmest } \\
\hline mestinjectie & $80,6 \%$ & $2,0 \%$ \\
\hline zodenbemester & $16,0 \%$ & $24,0 \%$ \\
\hline sleufkouter & $0,0 \%$ & $30,0 \%$ \\
\hline bovengronds mest en slib & $0,2 \%$ & $69,0 \%$ \\
\hline bovengronds compost & & $69,0 \%$ \\
\hline \multicolumn{3}{|l|}{ Onbeteeld bouwland - vaste mest } \\
\hline onderwerken in 2 werkgangen & $97,0 \%$ & $46,0 \%$ \\
\hline bovengronds mest en slib & $3,0 \%$ & $69,0 \%$ \\
\hline
\end{tabular}


Wageningen Environmental Research Postbus 47

6700 AA Wageningen

T 0317480700

www.wur.nl/environmental-research

Wageningen Environmental Research Rapport 3124

ISSN 1566-7197
De missie van Wageningen University \& Research is 'To explore the potential of nature to improve the quality of life'. Binnen Wageningen University \& Research bundelen Wageningen University en gespecialiseerde onderzoeksinstituten van Stichting Wageningen Research hun krachten om bij te dragen aan de oplossing van belangrijke vragen in het domein van gezonde voeding en leefomgeving. Met ongeveer 30 vestigingen, 6.800 medewerkers ( $6.000 \mathrm{fte}$ ) en 12.900 studenten behoort Wageningen University \& Research wereldwijd tot de aansprekende kennisinstellingen binnen haar domein. De integrale benadering van de vraagstukken en de samenwerking tussen verschillende disciplines vormen het hart van de unieke Wageningen aanpak. 


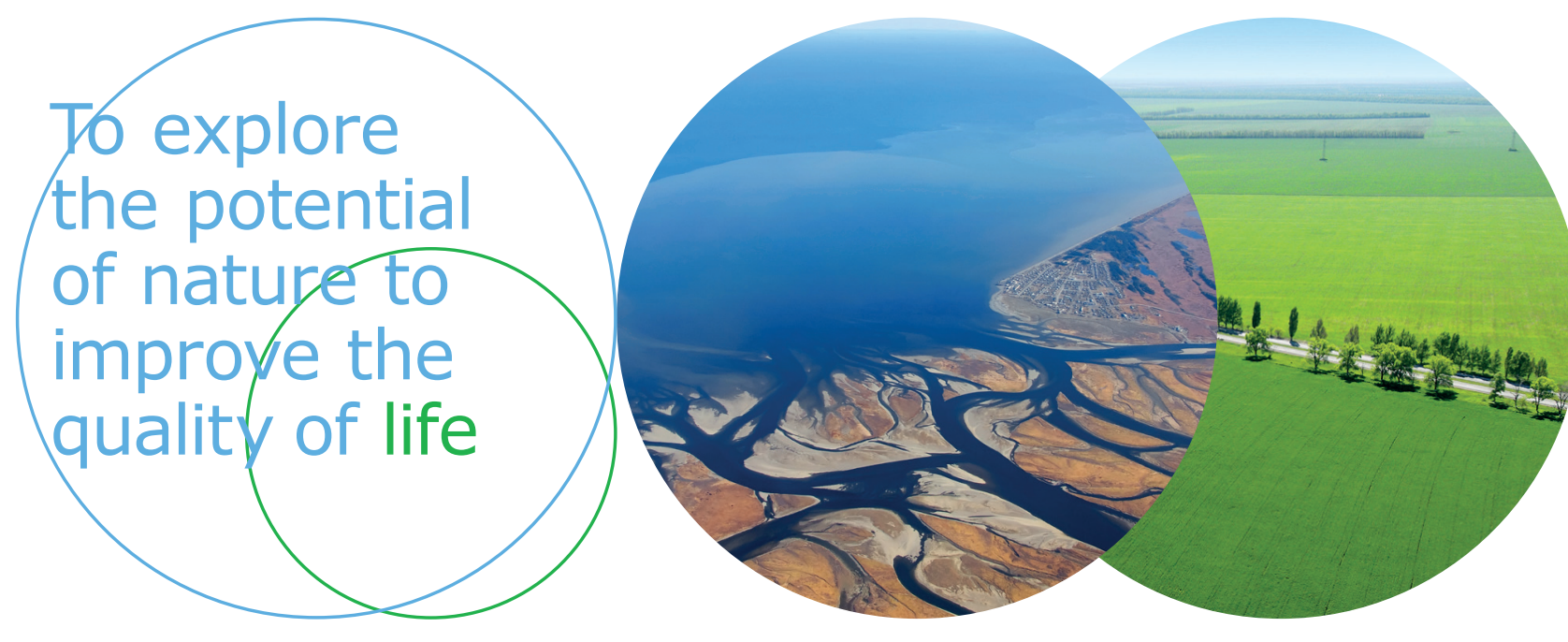

Wageningen Environmental Research Postbus 47

$6700 \mathrm{AB}$ Wageningen

T 317480700

www.wur.nl/environmental-research

Rapport 3124

ISSN 1566-7197
De missie van Wageningen University \& Research is 'To explore the potential of nature to improve the quality of life'. Binnen Wageningen University \& Research bundelen Wageningen University en gespecialiseerde onderzoeksinstituten van Stichting Wageningen Research hun krachten om bij te dragen aan de oplossing van belangrijke vragen in het domein van gezonde voeding en leefomgeving. Met ongeveer 30 vestigingen, 6.800 medewerkers (6.000 fte) en 12.900 studenten behoort Wageningen University \& Research wereldwijd tot de aansprekende kennisinstellingen binnen haar domein. De integrale benadering van de vraagstukken en de samenwerking tussen verschillende disciplines vormen het hart van de unieke Wageningen aanpak. 